\title{
System Specification \\ For The \\ Integrated Monitoring and Surveillance System
}

Plutonium Focus Area

Published September 1997

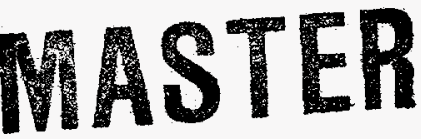

Idaho National Engineering and Environmental Laboratory

U.S. Department of Energy Idaho Operations Office Idaho Falls, ID 83415

Prepared For The

U.S. Department Of Energy

Nuclear Materials Stabilization Task Group

Under DOE Idaho Operations Office

Contract DE-AC07-94ID13223 


\section{DISCLAIMER}

This report was prepared as an account of work sponsored by an agency of the United States Government. Neither the United States Government nor any agency thereof, nor any of their employees, makes any warranty, express or implied, or assumes any legal liability or responsibility for the accuracy, completeness, or usefulness of any information, apparatus, product, or process disclosed, or represents that its use would not infringe privately owned rights. Reference herein to any specific commercial product, process, or service by trade name, trademark, manufacturer, or otherwise does not necessarily constitute or imply its endorsement, recommendation, or favoring by the United States Government or any agency thereof. The views and opinions of authors expressed herein do not necessarily state or reflect those of the United States Government or any agency thereof. 


\section{DISCLAIMER}

Portions of this document may be illegible electronic image products. Images are produced from the best available original document. 


\section{CONTENTS}

\section{LIST OF ILLUSTRATIONS}

1. SCOPE.

1.1 IDENTIFICATION

1.2 PURPOSE. .1

1.3 DOCUMENT OVERVIEW

1.3.1 System Operational Concept.

1.3.2 System Logistical Considerations and Concept.

1.3.3 Pertinent Requirements.

1.3.4 Internal and External Interfaces.

1.3.5 System Quality, Reliability, and Maintainability Factors...

1.3.6 Qualification Methods for Verifying Compliance with Requirements ............................................................

1.3.7 Traceability Of Requirements To Their Sources................................................................................................

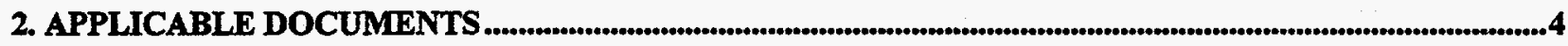

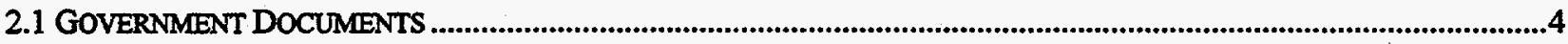

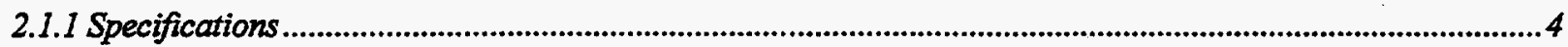

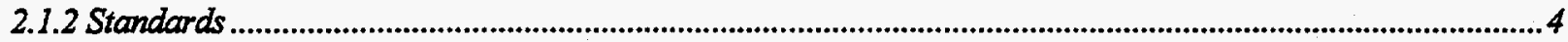

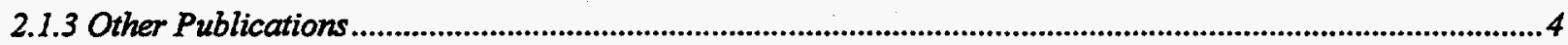

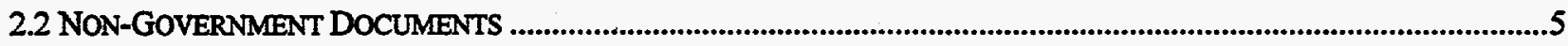

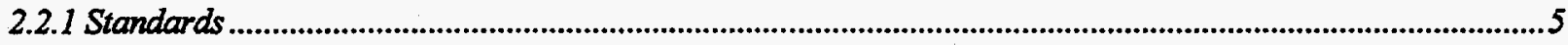

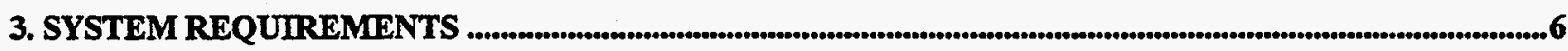

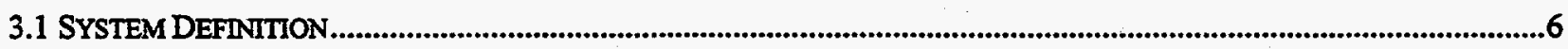

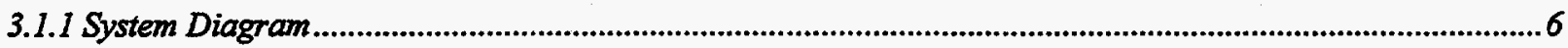

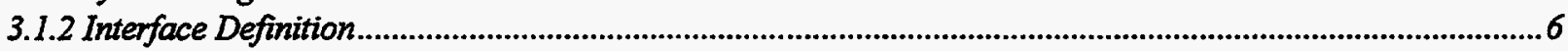

3.1.3 Major Component List ....................................................................................................................................

3.1.4 Government Furnished Property List ........................................................................................................................7

3.1.5 Government Loaned Property List.............................................................................................................

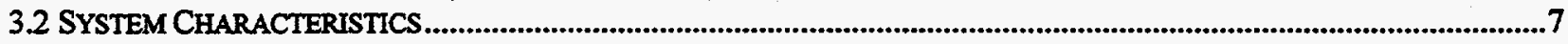

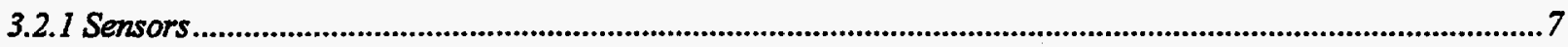

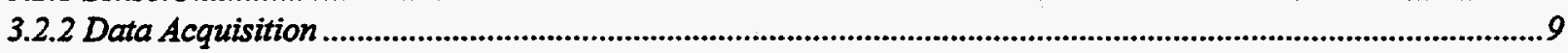

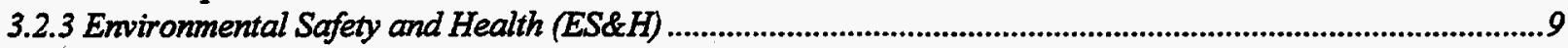

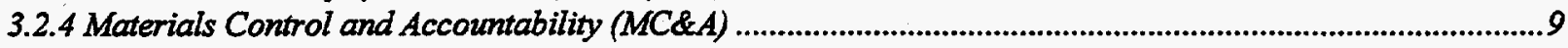

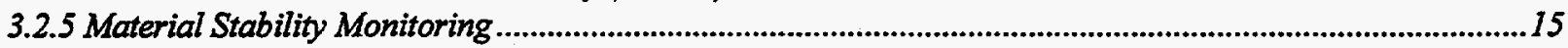

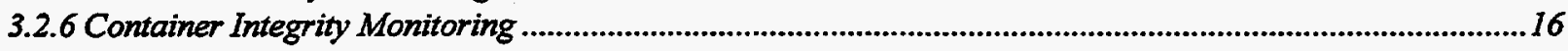

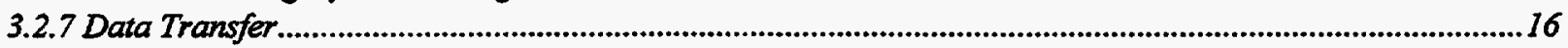

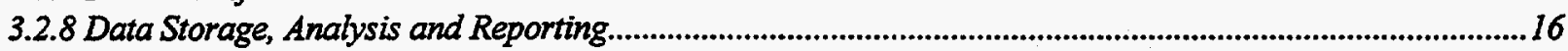

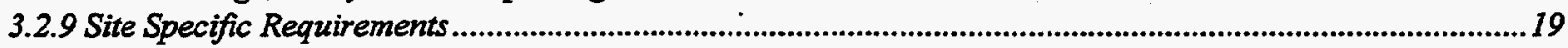

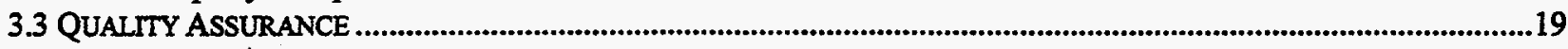

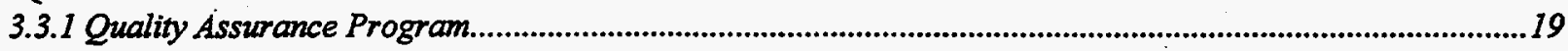

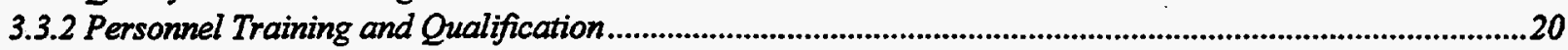

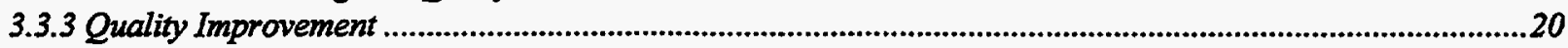

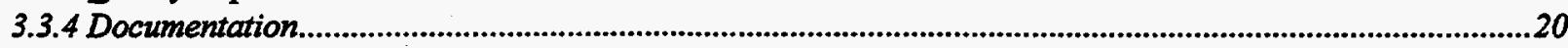

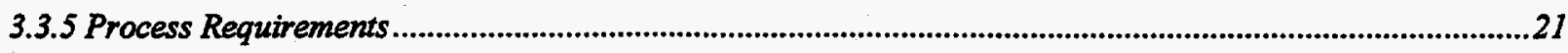

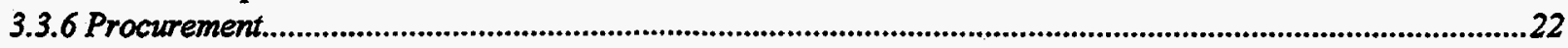

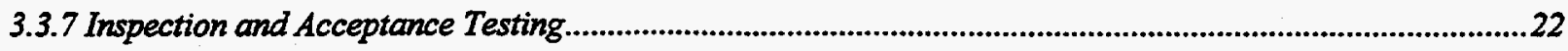

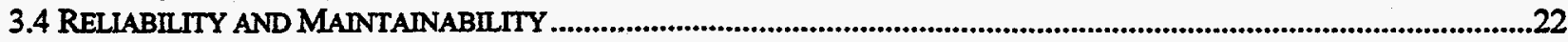

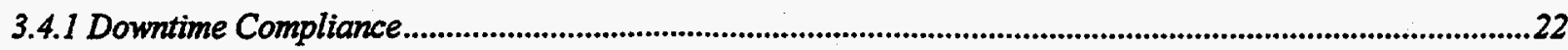


3.4.2 Downtime

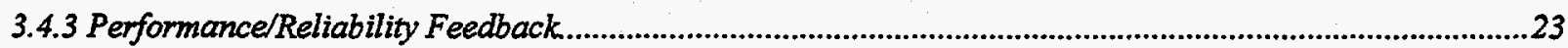

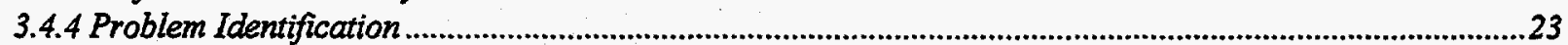

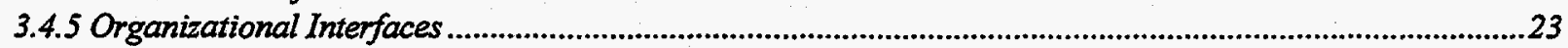

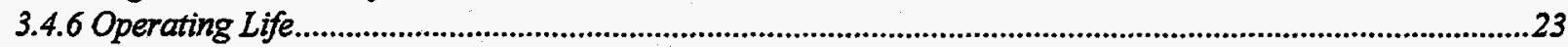

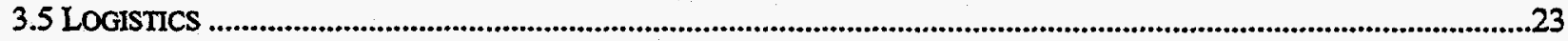

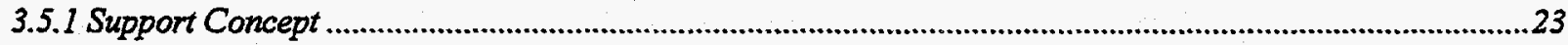

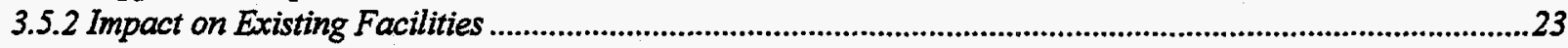

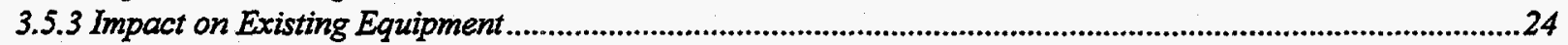

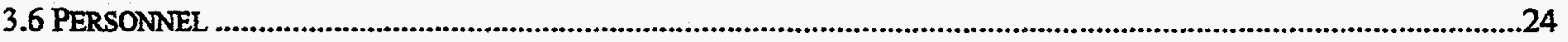

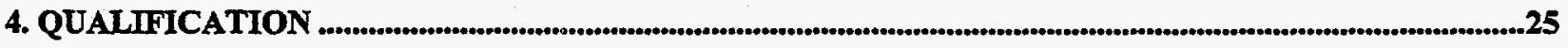

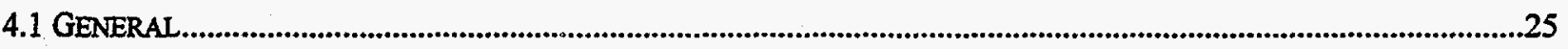

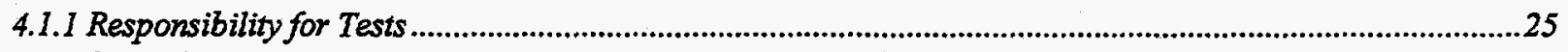

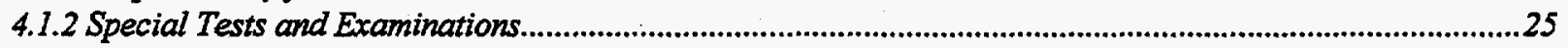

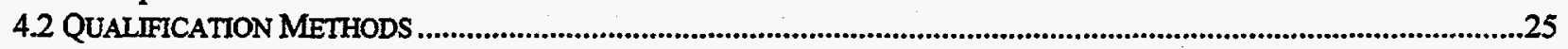

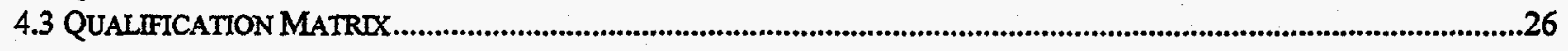

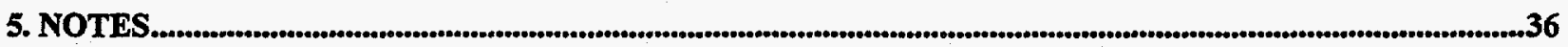

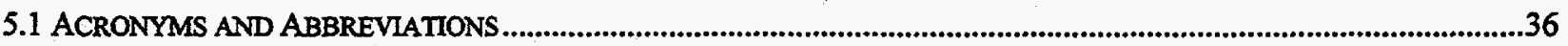

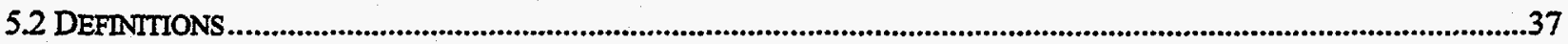

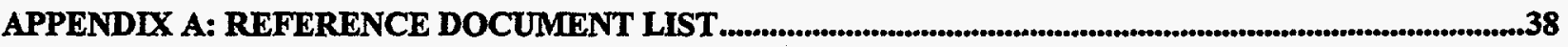

APPENDIX B: REQUIREMENTS TRACEABILITY MATRIX

\section{LIST OF ILLUSTRATIONS}

FIGURE 3-1 INTEGRATED MONITORNG AND SURVELLLANCE SYSTEM DIAGRAM 


\section{SCOPE}

\subsection{Identification}

This System Specification establishes the requirements for the Plutonium Focus Area (PFA) Integrated Monitoring and Surveillance System (IMSS). In this document, "Integrated Monitoring and Surveillance System" is used to describe the concept of integrated sensors, computers, personnel, and systems that perform the functions of sensing conditions, acquiring data, monitoring environmental safety and health, controlling and accounting for materials, monitoring material stability, monitoring container integrity, transferring data, and analyzing, reporting, and storing data. This concept encompasses systems (e.g. sensors, personnel, databases, etc.) that are already in place at the sites but may require modifications or additions to meet all identified surveillance requirements.

\subsection{Purpose}

The purpose of this System Specification is to provide Department of Energy (DOE) sites that store plutonium materials with a consolidation of all known requirements for the storage and surveillance of 3013 packages of stabilized plutonium metals and oxides. This compilation may be used (1) as a baseline for surveillance system design specifications where 3013 packages of stabilized plutonium metals and oxides will be stored and monitored; (2) as a checklist for evaluating existing surveillance systems to ensure that all requirements are met for the storage and surveillance of 3013 packages of stabilized plutonium metals and oxides; and (3) as a baseline for preparing procurement specifications tailored for site specific storage and surveillance of 3013 packages of stabilized plutonium metals and oxides.

It should be noted that:

- This System Specification does NOT include any requirement for CONTINUOUS monitoring of 3013 packages

- The scope of this System Specification specifically excludes identification of International Atomic Energy Agency (IAEA) requirements.

\subsection{Document Overview}

This document defines :

- The system operational concept

- The system logistical considerations and concepts

- Pertinent requirements

- Internal and external interfaces

- System quality, reliability, and maintainability factors 
- Qualification methods for verifying compliance with requirements

- Traceability of requirements to their sources.

\subsubsection{System Operational Concept}

This specification is written, primarily, to define and describe the system requirements to be used as constraints for the design and development of an IMSS for 3013 packages of plutonium metals and oxides. This specification provides the framework from which the system concept can develop into a final design. Because the storage locations, existing systems, and operating practices vary from site to site, the operational concept will be site specific and must be developed at each operating location. Most of the paragraphs that must be tailored to the individual DOE sites are highlighted with italics and are located throughout sections 3.1, 3.5, and 3.6 of this specification. Section 3.2 requirements should be closely examined as well since a number of them refer to site specific documentation, such as Safety and Analysis Reports (SARs) and Material Control and Accountability Plans (MCAPs). These site specific documents may need to be generated or modified to bring the sites into full compliance with DOE orders and standards regarding 3013 packages of plutonium metals and oxides. The resulting tailored operational concept will become a part of the overall system specification for the site.

\subsubsection{System Logistical Considerations and Concept}

Section 3.5 of this specification discusses logistical considerations and conditions as they apply to IMSS operations. Because the storage locations, existing systems, and operations vary from site to site, the logistics concept and considerations will be site specific and must be developed at each operating location. These tailored logistics requirements will become a part of the overall system specification for the site.

\subsubsection{Pertinent Requirements}

Section 3 of this specification contains all pertinent requirements for an IMSS for 3013 packages of plutonium metals and oxides. These requirements have been extracted directly or were derived from the documents listed in Appendix A.

\subsubsection{Internal and External Interfaces}

Section 3.1.2 of this specification discusses the internal and external IMSS interfaces. Because the storage locations, existing systems, and operations vary from site to site, these interfaces will be site specific and must be developed at each operating location. These tailored interface requirements will become a part of the overall system specification for the site.

\subsubsection{System Quality, Reliability, and Maintainability Factors}

Section 3.3.3 of this specification discusses the detection and prevention of quality problems for the IMSS. Reliability and maintainability issues are discussed in Section 3.4. Because the 
storage locations, existing systems, and operations vary from site to site, these issues will be site specific, with differing implementations at each operating location. These tailored system quality, reliability, and maintainability factors will become a part of the overall system specification for the site.

\subsubsection{Qualification Methods for Verifying Compliance with Requirements}

Section 4.2 of this specification discusses the five methods to be used to verify compliance with the requirements contained in Section 3 . Section 4.3 consists of a matrix, matching these methods with each specific requirement.

\subsubsection{Traceability Of Requirements To Their Sources}

Appendix B to this specification identifies the origin of each requirement contained in Section 3. 


\section{APPLICABLE DOCUMENTS}

The following documents form a part of this specification to the extent specified herein. In the event of conflict between the requirements of this specification and any referenced document, the requirements of the referenced document shall take precedence.

\subsection{Government Documents}

\subsubsection{Specifications}

10CFR 830.120

DOE O 232.1-1

DOE M 232.1-1

DOE $1360.2 B$

DOE 5630.11B

DOE 5630.16A

DOE 5632.1C

DOE M 5632.1C-1

DOE 5633.3B

\subsubsection{Standards}

DOE-STD-3013-96
Quality Assurance Requirements, January 1, 1996

Occurrence Reporting and Processing of Operations Information, August 12, 1996

Occurrence Reporting and Processing of Operations Information, September 25, 1995

Unclassified Security Program, May 18, 1992

Safeguards and Security Program, August 2, 1994

Safeguards and Security Acceptance and Validation Testing Program, June 3, 1993

Protection and Control of Safeguards and Security Interests, July 15, 1994 (Pending Revision)

Manual for Protection and Control of Safeguards and Security Interests, July 15, 1994 (Pending Revision)

Control and Accountability of Nuclear Materials, September 7, 1994

Criteria for Preparing and Packaging Plutonium Metals and Oxides for Long-Term Storage, September 1, 1996

\subsubsection{Other Publications}

CG-SS-3, E.O. Update Classification Guide for Safeguards and Security Information, E.O. Update, August 1, 1994 


\subsection{Non-Government Documents}

\subsubsection{Standards}

ANSI N323-1993

Radiation Protection Instrumentation Test and Calibration 


\section{SYSTEM REQUIREMENTS}

\subsection{System Definition}

\subsubsection{System Diagram}

The IMSS shall conform to the system diagram shown in Figure 3-1.

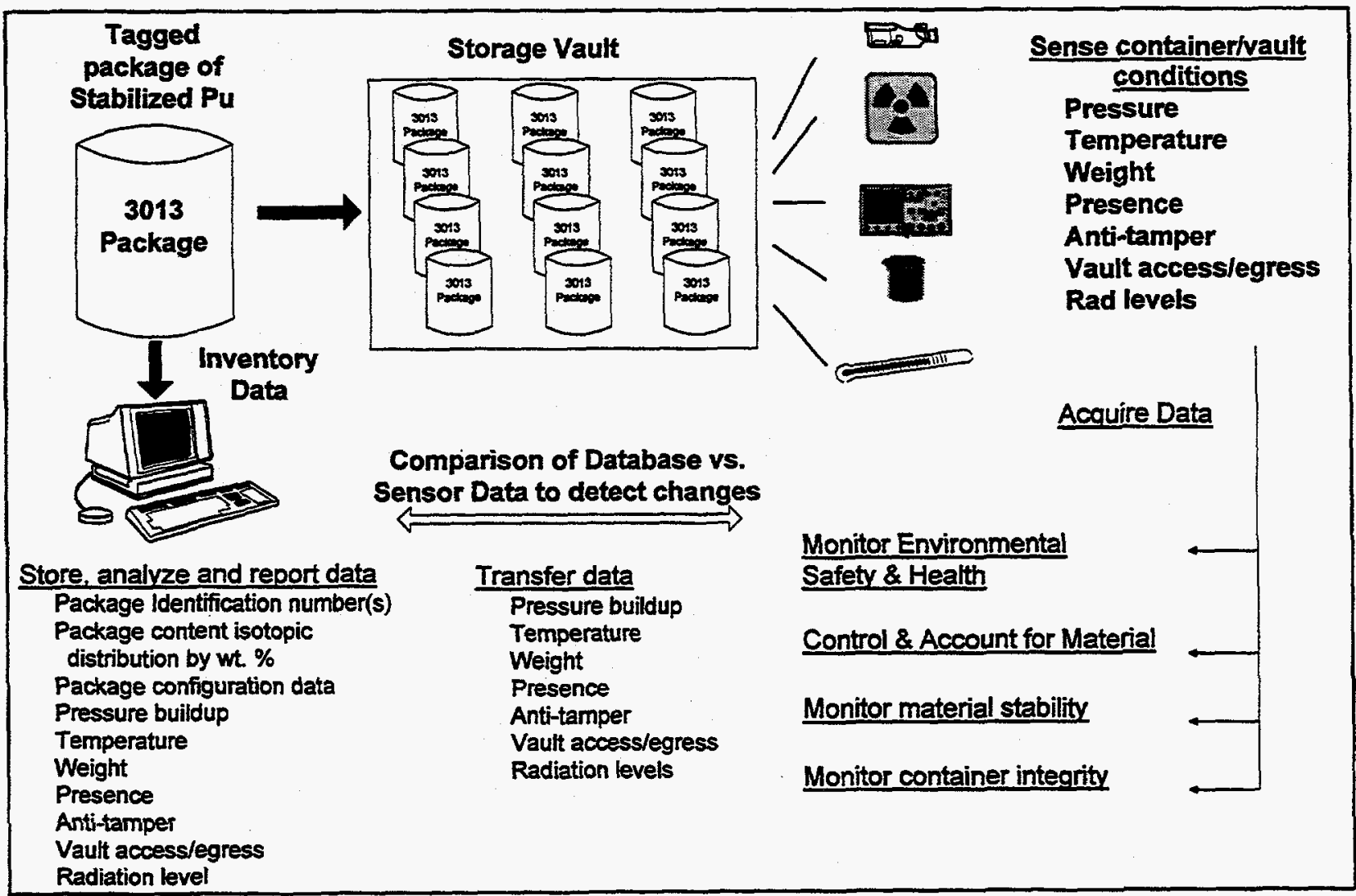

Figure 3-1. Integrated Monitoring and Surveillance System Diagram

\subsubsection{Interface Definition}

(Preparer: The following subparagraphs shall describe the external and internal interfaces with the IMSS at the specific long-term plutonium metals and oxides storage facility to which this specification applies. These descriptions shall include detailed, quantitative interface requirements. The detailed requirements may be defined in separate specifications or interface control documents and referenced herein.)

3.1.2.1 External Interfaces. (Preparer: This paragraph shall describe other systems with which the IMSS interfaces at the specific plutonium storage facility to which this specification applies. Each hardware and software interface between the IMSS and other systems shall be 
identified and specified in quantitative term (e.g., facility furnished electrical power and space; physical characteristics; data format; communication protocols.))

3.1.2.2 Internal Interfaces. (Preparer: This paragraph shall identify and specify in quantitative terms any internal hardware and software interfaces that are essential to meet system needs. To achieve maximum system design flexibility, the internal interfaces should be left open for the contractor to define as the design is developed.)

\subsubsection{Major Component List}

(Preparer: This paragraph shall list the major components, including computer software, to which the system requirements shall be allocated. This list shall be tailored to the specific longterm plutonium metals and oxides storage facility to which this specification applies.)

\subsubsection{Government Furnished Property List}

(Preparer: This paragraph shall specify any Government Furnished Equipment (GFE) to be incorporated into the IMSS design. In addition, this paragraph shall specify any Government Furnished Information (GFI) and Government Furnished Software (GFS) to be incorporated into the system. This list shall identify the Government furnished property by reference to its nomenclature, specification number, and/or part number as appropriate. If not applicable, state "Not applicable.")

\subsubsection{Government Loaned Property List}

Preparer: This paragraph shall specify any Government loaned property to be incorporated into the IMSS design. This list shall identify the Government loaned property by reference to its nomenclature, specification number, andlor part number as appropriate. If not applicable, state "Not applicable.")

\subsection{System Characteristics}

IMSS system characteristics shall be as specified in the following subparagraphs.

\subsubsection{Sensors}

\subsubsection{Storage Area Sensing.}

3.2.1.1.1 Radiological Conditions-The IMSS shall detect the radiological conditions of each storage area as prescribed in the facility Safety and Analysis Report (SAR).

3.2.1.1.1.1 Radiological Measurements. The measurement specifications for radiological conditions of each storage area are as prescribed in the facility SAR or RADCON manuals. 


\subsubsection{Package Sensing.}

3.2.1.2.1 Internal Container Pressure-The IMSS shall measure the internal container for an indication of pressurization before the pressure reaches $100 \mathrm{psig}$.

3.2.1.2.2 Temperature Range-The IMSS shall have the capability to measure the package/container temperature over a range of 0 to $450 \mathrm{deg} C$.

3.2.1.2.2.1 Temperature Accuracy. The accuracy of the temperature measurement shall be sufficient to ensure that the stored material temperature does not exceed $100 \mathrm{deg} C$ for alpha plutonium metals and $400 \mathrm{deg} C$ for plutonium oxides (at 30 watt maximum thermal output per package).

3.2.1.2.3 Package Weight Range-The IMSS shall measure the weight of each package over a range of 0 to $15.0 \mathrm{~kg}$.

3.2.1.2.3.1 Package Weight Accuracy. The IMSS shall measure the weight of each container using measurement control practices as defined in DOE 5633.3B, chapter II section 4.e.

3.2.1.2.4 Package Radiation Levels-The IMSS shall measure the gamma and neutron radiation levels of each package in accordance with the site Materials Control and Accountability (MC\&A) Plan.

3.2.1.2.5 Package Condition-The IMSS shall inspect packages for signs of leakage, degradation or corrosion.

\subsubsection{Sensor Environmental Conditions.}

3.2.1.3.1 Sensor Operating Temperature-The IMSS sensors shall be capable of operating at ambient storage area temperatures.

3.2.1.3.2 Sensor Operating Humidity-The IMSS sensors shall be capable of operating at ambient storage area humidities.

3.2.1.3.3 Sensor Operating Radiological Environment-The IMSS sensors shall be capable of operating in the storage area radiological environment as specified in the site Materials Control and Accountability(MC\&A) Plan.

3.2.1.3.4 Sensor Technology-The IMSS shall use nonintrusive technologies that minimize personnel exposures. 


\subsubsection{Data Acquisition}

3.2.2.1 Data Categories. The Integrated Monitoring and Surveillance System shall acquire data pertinent to Environmental Safety and Health compliance, Material Control and Accountability, material stability, and container integrity.

\subsubsection{Environmental Safety and Health (ES\&H)}

3.2.3.1 Alarm Parameters. Alarm indicators and monitoring signal readouts shall be included for parameters that have an impact on safety in accordance with the site Safety Requirements Document and Safety Analysis Report (SAR).

3.2.3.2 Radiological Instruments. The IMSS shall include instruments that are responsive to the radiological conditions at the storage area.

3.2.3.3 ANSI Compliance. Radiation monitoring instruments for plutonium shall comply with ANSI N323-1993, section 4.

3.2.3.4 Gamma Radiation Monitoring. The IMSS shall monitor the storage area for gamma radiation in accordance with the site Safety Analysis Report (SAR).

3.2.3.5 Neutron Radiation Monitoring. The IMSS shall monitor the storage area for neutron radiation in accordance with the site Safety Analysis Report (SAR).

3.2.3.6 Monitoring and Test Interval. The monitoring and test interval for Environmental, Safety, and Health (ES\&H) surveillance instruments shall be in accordance with the Site ES\&H Manual.

3.2.3.7 Scheduling. A schedule shall be maintained for continuing safety and safeguards surveillance testing.

3.2.3.8 Inspection Coordination. Safety inspections should be integrated with other required inspections (e.g., Materials Control and Accountability) and maintenance and shall be nonintrusive.

\subsubsection{Materials Control and Accountability (MC\&A)}

\subsubsection{Control.}

\subsection{Alarm and Anti-tamper-}

3.2.4.1.1.1 Unauthorized/Unaccompanied Entry. Surveillance shall be sufficient to assure that unauthorized or unaccompanied authorized personnel cannot enter the storage area undetected when the door is unlocked or open. 
3.2.4.1.1.2 Auxiliary Power. Intrusion detection and access control systems shall have auxiliary power sources as specified in DOE M 5632.1C-1, chapter VI section 7 and chapter VII section 2.b.

3.2.4.1.1.3 intrusion Detection and Assessment. IMSS monitoring elements or equipment that are used for safeguards and security purposes, such as intrusion detection and assessment, shall comply with DOE Order M 5632.1C-1, chapter VI .

3.2.4.1.1.4 Radio Frequency Device Compliance. Radio frequency (RF) alarm communication devices shall comply with the Office of Safeguards and Security requirements and guidelines for use in the protection of Category I (Cat I) Special Nuclear Materials (SNM) in accordance with DOE O 5632.1C and DOE M-5632.1C-1.

3.2.4.1.1.4.1 Radio Frequency Device Limitations - $R F$ alarm systems, when used with Category I Special Nuclear Materials (SNM), shall be limited to emergencies and temporary situations.

3.2.4.1.1.4.2 Radio Frequency Device Temporary Usage-Emergency and temporary use of $R F$ alarm systems shall not exceed 120 days per application.

\subsubsection{MC\&A Planning and Testing.}

\subsection{Site MC\&A Plan-}

3.2.4.2.1.1 Graded Approach. Each facility shall implement a graded surveillance program for monitoring nuclear materials, as specified in DOE 5633.3B, chapter III, section 3.

3.2.4.2.1.2 Surveillance Interval. The surveillance interval for MC\&A purposes shall be as specified in the Site MC\&A Plan.

3.2.4.2.1.3 Surveillance Requirements. The Materials Control and Accountability (MC\&A) plan for facilities storing Category I and II quantities of special nuclear material shall include requirements for surveillance.

3.2.4.2.1.4 Threat Considerations. The Materials Control and Accountability (MC\&A) plan for facilities storing Category I and II quantities of special nuclear material shall reflect requirements for threat considerations.

3.2.4.2.1.5 Accounting System. The Materials Control and Accountability (MC\&A) plan for facilities storing Category I and II quantities of special nuclear material shall include requirements for the accounting system. 
3.2.4.2.1.6 Physical Inventories. The Materials Control and Accountability (MC\&A) plan for facilities storing Category I and II quantities of special nuclear material shall include requirements for physical inventories.

3.2.4.2.1.7 Measurement Control. The Materials Control and Accountability (MC\&A) plan for facilities storing Category I and II quantities of special nuclear material shall include requirements for measurement control.

3.2.4.2.1.8 Control Limits. The Materials Control and Accountability (MC\&A) plan for facilities storing Category I and II quantities of special nuclear material shall include requirements for control limits.

\subsection{Loss Detection Elements. The Materials Control and Accountability} (MC\&A) plan for facilities storing Category I and II quantities of special nuclear material shall include requirements for loss detection elements.

3.2.4.2.1.10 Response to Nuclear Material Alarms. The Materials Control and Accountability (MC\&A) plan for facilities storing Category I and II quantities of special nuclear material shall include requirements for response to nuclear material alarms.

3.2.4.2.1.11 Anomaly Resolution. The Materials Control and Accountability (MC\&A) plan for facilities storing Category I and II quantities of special nuclear material shall include requirements for anomaly resolution.

\subsection{Program Planning And Management. The Materials Control and} Accountability (MC\&A) plan for facilities storing Category I and II quantities of special nuclear material shall include requirements for M\&CA program planning and management.

3.2.4.2.1.13 Performance Criteria. The Materials Control and Accountability (MC\&A) plan for facilities storing Category I and II quantities of special nuclear material shall include requirements for system element performance per DOE 5633.3B, chapter I, section 4.C.

3.2.4.2.1.14 Administrative Control. The Materials Control and Accountability (MC\&A) plan for facilities storing Category I and II quantities of special nuclear material shall comply with the administrative control requirements as specified in DOE 5633.3B, chapter I, section 6 .

3.2.4.2.1.14.1 Procedure Review and Approval-Facility materials control and accountability procedures shall be reviewed and approved in accordance with DOE 5633.3B, chapter I, section 6.a. 
3.2.4.2.1.14.2 Formal Documentation-Formal (inspection and surveillance) methods and responsibilities shall be documented and maintained for independent review and evaluation.

\subsection{MC\&A Testing-}

3.2.4.2.2.1 IAEA and NRC Standards. The IMSS shall use procedures, techniques, and standards as promulgated by the International Atomic Energy Agency (IAEA) and the Nuclear Regulatory Commission (NRC), in developing the basis for nuclear material control, measurements, and measurement control, accounting, and statistical methods, when appropriate and consistent with DOE regulatory goals.

3.2.4.2.2.2 ASTM and ANSI Standards. The IMSS shall use procedures, techniques, and standards as promulgated by the American Society for Testing and Materials (ASTM) and the American National Standards Institute (ANSI), when such standards exist, in developing the basis for nuclear material control, measurements, and measurement control, accounting, and statistical methods that are employed for safeguarding of nuclear materials, unless otherwise directed by DOE directives.

3.2.4.2.2.2.1 Working Standards-Working standards used in a measurement control program shall be representative of the type and composition of the material being measured when the material matrix affects the measured value.

3.2.4.2.2.3 Test Conduct. Testing of all monitoring, surveillance and alarm systems shall be conducted in accordance with the testing methodology, testing frequency and record maintenance requirements as prescribed in DOE 5630.16A, DOE M 5632.1C-1, chapter VI section 8, DOE 5630.11B, DOE 1360.2B and the site SAR test plan.

3.2.4.2.2.4 Functionality. Materials control and accountability tests shall be designed to demonstrate that the MC\&A system is functional.

3.2.4.2.2.5 Performance. Materials control and accountability tests shall assure that the MC\&A system performs as specified.

3.2.4.2.2.6 Detection of Unauthorized Actions. In at least 95\% of material surveillance effectiveness tests, the tests shall demonstrate the detection of unauthorized actions related to the control of Category I and II quantities of special nuclear material.

3.2.4.2.2.7 Surveillance Effectiveness. Performance tests shall be designed and conducted to fully evaluate the effectiveness of material surveillance activities for Category I and II quantities of special nuclear material. 
3.2.4.2.2.8 Documented Testing Program. For each facility, management shall establish and implement a documented testing program to verify materials control and accountability procedures and practices.

3.2.4.2.2.9 Facility Specific Scope. Testing of access controls and materials surveillance shall be facility-specific with the scope and extent of the testing documented by facility management and approved by Manager, Operations Office.

\subsubsection{Accountability.}

\subsection{Package Identification-}

3.2.4.3.1.1 Labels. The IMSS shall be capable of identifying 3013 packages which are permanently and uniquely labeled as specified in the site operating procedures.

\subsection{Verification Measurement-}

3.2.4.3.2.1 Attribute Confirmation. Packages shall be subjected to confirmatory measurements of a specific attribute per DOE 5633.3B, chapter II section 3.d.

\subsection{1 Confirmation Acceptance/Rejection Criteria-Confirmatory measurements shall be capable of determining the presence or absence of a specific attribute of the material, consistent with valid acceptance/rejection criteria.}

3.2.4.3.2.2 Control Limits. The control limits for acceptance/rejection criteria of inventory confirmation/verification measurements shall be set at no wider than three times the standard deviation for the method.

3.2.4.3.2.3 Measurement Method Standard Deviation. The acceptance/rejection criteria for inventory verification measurements, and where possible for inventory confirmation measurements, shall be based on the standard deviation for the measurement method under operating conditions.

3.2.4.3.2.4 Statistical Sampling. A statistical sampling of the stored packages shall be subjected to confirmatory measurements in accordance with the site Materials Control and Accountability (MC\&A) Plan.

\subsection{MC\&A Data Records-MC\&A Data Records}

3.2.4.3.3.1 Package Identity and Location Accuracy. The accounting record system shall accurately reflect item identity and location in at least $99 \%$ of the cases. 
3.2.4.3.3.2 Confirmation Data. Material control and accountability (MC\&A) data shall include any available measurement data that can be used to confirm the presence of items, such as neutron coincidence counter (NCC) and gamma isotopic data.

3.2.4.3.3.3 Material Transfer Data. Material control and accountability (MC\&A) data shall include material transfer data in accordance with DOE 5633.3B, chapter II, section 5.

3.2.4.3.3.4 Gamma Data. Material control and accountability (MC\&A) data shall include available gamma assay or analysis data.

3.2.4.3.3.5 Neutron Data. Material control and accountability (MC\&A) data shall include available neutron assay or analysis data.

3.2.4.3.3.6 Weight Data. Material control and accountability (MC\&A) data shall include available tare and gross weights.

3.2.4.3.3.7 NDA Data. Material control and accountability (MC\&A) data shall include available NDA measurement results (if applicable).

3.2.4.3.3.8 Chemistry Data. Material control and accountability (MC\&A) data shall include available chemistry results.

3.2.4.3.3.9 Analysis and Separation Data. Material control and accountability (MC\&A) data shall include dates of analysis and/or separation for $\mathrm{Pu}$ isotopes and $\mathrm{Am}$ to allow calculation of future composition.

3.2.4.3.3.10 Chemical Format Data. Material control and accountability (MC\&A) data shall include identification of chemical form (e.g., plutonium metal, plutonium oxide), quantities of accountable elements and isotopic distribution (e.g. \% $238 \mathrm{Pu}, \% 239 \mathrm{Pu}, \%$ $240 \mathrm{Pu}, \% 241 \mathrm{Pu}, \% 242 \mathrm{Pu}$ ).

3.2.4.3.3.11 Tamper Indication Data. For those packages containing tamper-indicating devices, the tamper-indicating device record system shall accurately reflect the location and identity of tamper-indicating devices in at least $99 \%$ of the cases.

\subsection{Physical Inventory-}

3.2.4.3.4.1 Physical Inventory Program Compliance. Stored materials shall be inventoried in accordance with the facility physical inventory program per DOE 5633.3B, chapter II section 3 .

3.2.4.3.4.2 Inventory Responsibilities. For each facility, there shall be documented plans and procedures defining responsibilities for performing inventories and specifying criteria 
for conducting, verifying, and reconciling inventories of nuclear material, as specified in DOE 5633.3B, chapter II, section 3.a.(2).

3.2.4.3.4.3 Inventory Frequency. For each facility, the frequency of physical inventories for Category I and II Materials Balance Areas shall be in accordance with DOE 5633.3B, chapter II, section 3 .

\subsubsection{Measurement Control.}

3.2.4.4.1 Weighing Systems Compliance-Weighing systems shall comply with the measurement control requirements in DOE 5633.3B, chapter II, section 4.e.

3.2.4.4.2 Weighing Systems Interface-Weighing systems shall have the capability to interface with IMSS remote recording equipment.

\subsubsection{Material Stability Monitoring}

3.2.5.1 Material Physical Changes. The surveillance system for these materials shall include monitoring for physical changes within the container.

3.2.5.2 Container Distortion. The surveillance system for these materials shall include monitoring for distortion of containers from pressurization.

3.2.5.2.1 Pressurization-The IMSS shall monitor the inner container for an indication of a buildup of internal pressure at less than 100 psig.

3.2.5.2.2 Container Deformation-Any indication of container deformation shall be evaluated.

3.2.5.3 Plutonium Metal Temperature Limit. The IMSS shall monitor the storage containers to ensure that the steady-state temperature of stored alpha plutonium metal shall not exceed $100 \mathrm{deg}$ C (212 deg F).

3.2.5.4 Plutonium Oxide Temperature Limit. The IMSS shall monitor the packages/containers for an indication of a temperature rise in excess of $400 \mathrm{deg} C$ for stored plutonium oxides(at 30 watt maximum thermal output per package).

3.2.5.5 Temperature and Pressure Calculations. Calculation of the pressure rise and heat generated in the sealed containers shall be in accordance with Appendix A of DOE-STD-301396.

3.2.5.6 Baseline Package Inspections. The IMSS plan shall include provision for initial baseline package inspections within 30 days of closure. 
3.2.5.7 Infant Mortality Monitoring Interval. During the package infant mortality period (i.e. at the start of the package service life), the IMSS shall monitor each package at intervals in accordance with the facility operating procedures.

3.2.5.8 Statistical Approach. For periodic surveillances throughout the storage period, surveillance frequency, sample population, and package selection shall be established by a statistical approach.

\subsubsection{Container Integrity Monitoring}

3.2.6.1 On-going Inspection Intervals. Non-intrusive surveillance of packages/containers shall be performed at prescribed intervals throughout the storage period to determine storage package integrity, including corrosion, and condition of the contents.

3.2.6.2 Statistical Approach. Surveillance frequency, sample population, and package selection shall be established by a statistical approach.

\subsubsection{Data Transfer}

3.2.7.1 Components. The Integrated Monitoring and Surveillance System shall include all components necessary to transfer signals and data between data input and data subsystems.

3.2.7.2 Software. The Integrated Monitoring and Surveillance System shall include all software necessary to transfer signals and data between data input and data subsystems.

\subsubsection{Data Storage, Analysis and Reporting}

\subsubsection{General.}

3.2.8.1.1 Database-A data base shall be maintained to serve as a source of relevant information about stored materials and containers. For completeness, MC\&A documentation shall be coordinated with the data base.

3.2.8.1.2 Compatibility-The IMSS shall store data in an electronic database in a form that is directly shareable between DOE sites.

3.2.8.1.3 Data Architecture-The IMSS shall employ an open systems architecture that does not employ vendor specific interfaces or system software.

3.2.8.1.4 Transferability-The implementation of the IMSS and its database shall employ an architecture that permits the transfer of IMSS data to DOE complex-wide users. 
3.2.8.1.5 Classified Data Separation-A database shall be provided and maintained which contains all classified data or data that when combined is classified.

3.2.8.1.5.1 Classification Guide. The IMSS classified data base shall be classified in accordance with CG-SS-3, Classification Guide for Safeguards and Security Information.

3.2.8.1.6 Data Access Contro/-For each facility, management shall establish controls that limit access to the M\&CA accounting system and nuclear materials accounting data.

\subsubsection{Data Storage.}

3.2.8.2.1 Material Transfer Data-The data base shall include MC\&A material transfer data in accordance with DOE 5633.3B, chapter II, section 5.

3.2.8.2.2 Material Location Data-The data base shall include locations of stored materials.

3.2.8.2.3 Analysis and Separation Data-The data base shall include dates of analysis and/or separation for $\mathrm{Pu}$ isotopes and Am to allow calculation of future composition.

3.2.8.2.4 Material Physical Description-The data base shall include description of material physical form and shape (e.g., solid metal or small pieces).

3.2.8.2.5 LOI Test Data-The data base shall include loss on ignition (LOI) test results and conditions of the tests.

3.2.8.2.6 Stabilization Test Data-The data base shall include all stabilization testing results.

3.2.8.2.7 Processing Conditions-The data base shall include specific processing condition(s).

3.2.8.2.7.1 Processing Data. Process conditions shall include, but are not limited to, stabilization temperature and atmosphere.

3.2.8.2.8 Package Configuration Data-The data base shall include package configuration - number (and type) of containers in package.

3.2.8.2.9 Packaging Date-The data base shall include date of packaging.

3.2.8.2.10 Initial Radiation Field Data-The data base shall include initial radiation field (gamma and neutron at contact and $30 \mathrm{~cm}$. (12 in.)). 
3.2.8.2.11 Chemical Form Data-The data base shall include identification of chemical form (e.g., plutonium metal, plutonium oxide), element and isotopic distribution (e.g. \% $238 \mathrm{Pu}, \% 239 \mathrm{Pu}, \% 240 \mathrm{Pu}, \% 241 \mathrm{Pu}, \% 242 \mathrm{Pu}$ ).

3.2.8.2.12 Material Source-The data base shall include the source of the stored material (facility that generated the material), if available.

3.2.8.2.13 Package Identification Number-The database shall include the unique package identification number associated with each container data record.

3.2.8.2.14 Surveillance Results-The data base shall include surveillance results.

3.2.8.2.15 Inspection Tests Performed-The data base shall include records of the inspection tests performed.

3.2.8.2.16 Individuals Performing Inspections-The data base shall include records of the names of individuals performing inspections.

3.2.8.2.17 Inspection Dates-The data base shall include records of the dates of inspections.

3.2.8.2.18 Fill Gas Data-The data base shall include fill gas composition on sealing.

3.2.8.2.19 Material Mass Data-The data base shall include identification of quantity (mass) of material contents.

3.2.8.2.20 Baseline Package Data-The data base shall include baseline package (gross) weight and dimensions.

3.2.8.2.21 Container Lot Identification Number-The data base shall include the manufacturer lot identification number for each container.

\subsubsection{Data Analysis.}

3.2.8.3.1 Weight Change Detection-The IMSS shall compare package weight measurements against the baseline measurements to detect change of weight of the container contents as applicable.

3.2.8.3.2 Temperature Change Detection-The IMSS shall compare the container temperature measurements against the baseline measurements to detect changes of temperature as applicable.

3.2.8.3.3 Errors/Discrepancies Detection-The facility nuclear materials accounting system shall include checks and balances and be structured to ensure timely detection 
(normally within 24 hours but in no case later than the subsequent inventory reconciliation) of errors/discrepancies in records associated with a Category I or II quantity of special nuclear material including detecting falsified data and identifying the responsible person(s).

3.2.8.3.4 Data Omission Detection-The facility nuclear materials accounting system shall include checks and balances and be structured to ensure identification of omission(s) of data for any reportable transaction.

3.2.8.3.5 Inventory Discrepancy Data-The facility nuclear materials accounting system shall include checks and balances and be structured to ensure detection of data discrepancies and errors to ensure that no discrepancies exist in control indicator counts.

\subsubsection{Data Reporting.}

3.2.8.4.1 Book Inventory Listings-The records system shall be capable of generating book inventory listings for all special nuclear materials within 3 hours.

3.2.8.4.2 Occurrence Reports-Reportable occurrences involving Category I, II and III nuclear materials shall be reported as an Emergency, Unusual Occurrence or Off-Normal Occurrence in accordance with DOE 5000.3B (replaced with DOE O 232.1-1and DOE M 232.1-1).

\subsubsection{Site Specific Requirements}

3.2.9.1 Package Transferability. Site specific plans, designs, and implementations of IMSS components and databases shall not preclude the movement of 3013 packages between sites or to long term storage.

\subsection{Quality Assurance}

\subsubsection{Quality Assurance Program}

3.3.1.1 DOE Approval. A Quality Assurance Program (QAP) shall be developed and submitted for approval by DOE.

3.3.1.2 Use of Standards. The IMSS shall use appropriate standards, wherever applicable, to develop and implement the QAP.

3.3.1.3 Change Review. QAP Changes made over the previous year shall be submitted annually to DOE for review.

3.3.1.4 CFR Compliance. A written QAP shall be developed, implemented, and maintained in accordance with 10 CFR 830.120, Subpart A, paragraph c (1) (I). 


\subsubsection{Personnel Training and Qualification}

3.3.2.1 Performance Training. Personnel shall be trained and qualified to ensure they are capable of performing their assigned work.

3.3.2.2 Continuing Training. Personnel shall be provided continuing training to ensure that job proficiency is maintained.

3.3.2.3 Documentation of Training Requirements. The site MC\&A plan shall reflect training requirements.

3.3.2.4 Measurement Training Plan. Each facility shall have a documented plan for the training of personnel who perform IMSS measurements.

3.3.2.5 Measurement Training. Each facility training plan shall specify training, qualification, and requalification requirements for each measurement method.

3.3.2.6 Proficiency Demonstration. Each facility shall have a documented qualification program that ensures that measurement personnel demonstrate acceptable levels of proficiency before performing measurements.

3.3.2.7 Requalification. Each facility qualification program shall ensure that measurement personnel are requalified according to the requirements of the facility training plan.

3.3.2.8 Certification. All personnel participating in any IMSS related processes and procedures shall be trained and certified as appropriate for their areas of involvement.

\subsubsection{Quality Improvement}

3.3.3.1 Processes. Processes to detect and prevent quality problems shall be established and implemented.

3.3.3.2 Process Deficiency /dentification. IMSS subsystem, item, and/or component reliability, process implementation, and other quality-related information shall be reviewed and the data analyzed to identify items and processes needing improvement.

\subsubsection{Documentation}

3.3.4.1 Document Review and Approval. Documents shall be prepared, reviewed, approved, issued, used, and revised to prescribe processes, specify requirements, or establish design.

3.3.4.2 Container Fabrication Records. The IMSS shall maintain Quality Assurance (QA) records for container fabrication. 
3.3.4.2.1 Outer Top Weld Data-Container data shall include Container Fabrication Data Record-Outer Top Weld.

3.3.4.2.2 Outer Bottom Weld Data-Container data shall include Container Fabrication Data Record--Outer Bottom Weld, if available.

3.3.4.2.3 Inner Top Weld Data - Container data shall include Container Fabrication Data Record--Inner Top Weld.

3.3.4.2.4 Inner Bottom Weld Data-Container data shall include Container Fabrication Data Record--Inner Bottom Weld.

3.3.4.2.5 Inner Can Helium Leak Test Data-Container data shall include Long Term Storage Container Helium Leak Test Data Record for the inner can.

3.3.4.2.6 Outer Can Helium Leak Test Data-Container data shall include Long Term Storage Container Helium Leak Test Data Record for the outer can.

3.3.4.3 Weighing Instrument Data. The IMSS shall maintain QA records for package/container weighing instruments.

3.3.4.3.1 Weight Data-Material control and accountability (MC\&A) data shall include weight information, including identification of the instrument used to weigh the package/container and date of measurement.

\subsubsection{Process Requirements}

3.3.5.1 Work Standards. Work shall be performed to established technical standards and administrative controls using approved instructions, procedures, or other appropriate means.

3.3.5.2 Equipment Calibration. Equipment used for process monitoring or data collection shall be calibrated and maintained.

3.3.5.3 Leak Testing. Essential procedures and processes covered by Quality Assurance and Quality Control (QC) requirements shall include (but will not be limited to) leak testing procedure used for certifying that containers are leak-tight at closure.

3.3.5.4 Database Recording. Essential procedures and processes covered by QA and QC requirements shall include (but are not limited to) data base recording procedure and characterization parameters addressed in Section 4.4.2 of DOE-STD-3013-96.

3.3.5.5 Rejected Items. Inspection and surveillance procedures shall be site-specific and shall identify specific instructions to ensure that rejected items are addressed in accordance with approved procedures and DOE reporting requirements. 
3.3.5.6 Acceptance Criteria. Inspection and surveillance procedures shall be site-specific and shall identify acceptance criteria.

3.3.5.7 Inspection and Surveillance Prerequisites. Inspection and surveillance procedures shall be site-specific and shall identify prerequisites.

3.3.5.8 Inspection and Surveillance Frequency. Inspection and surveillance procedures shall be site-specific and shall identify frequency of inspection.

3.3.5.9 Safety Inspection Documentation. Safety inspection and surveillance methods and responsibilities shall be documented and maintained for independent review and evaluation.

3.3.5.10 Surveillance Procedures. Essential procedures and processes covered by QA requirements shall include (but will not be limited to) surveillance procedure(s).

\subsubsection{Procurement}

3.3.6.1 Performance. Procured items and services shall meet established requirements and perform as specified.

\subsubsection{Inspection and Acceptance Testing}

3.3.7.1 Equipment Calibration. Equipment used for inspections and tests shall be calibrated and maintained.

3.3.7.2 Measurement Methods. IMSS measurement methods capable of providing the desired levels of precision and accuracy shall be selected, qualified, and validated by each facility's management in accordance with DOE 5633.3b.

\subsection{Reliability and Maintainability}

\subsubsection{Downtime Compliance}

Automated IMSS surveillance equipment used in plutonium storage areas shall have adequate reliability, and incorporate sufficient maintainability design features such as fault detection, fault isolation and redundancy, to meet the IMSS downtime requirements as specified in the site MC\&A Plan.

\subsubsection{Downtime}

The site MC\&A Plan shall specify the IMSS downtime requirements. 


\subsubsection{Performance/Reliability Feedback}

The IMSS shall include, or be included in, a Maintenance Plan approved by the field element that clearly defines mechanisms for feedback of relevant information such as instrumentation performance/reliability data to identify necessary system modifications.

\subsubsection{Problem Identification}

The IMSS shall include, or be included in, a Maintenance Plan approved by the field element that includes provisions for identification, evaluation, and correction of possible component, system design, quality assurance, or other relevant problems.

\subsubsection{Organizational Interfaces}

The IMSS shall include, or be included in, a Maintenance Plan approved by the field element that clearly defines interfaces between maintenance and other organizations (i.e. operations, engineering, quality, training, environment, safety, and health).

\subsubsection{Operating Life}

The IMSS shall have a life cycle of 50 years with periodic maintenance and upgrades as required.

\subsection{Logistics}

(Preparer: The following subparagraphs shall specify logistic considerations and conditions that apply to IMSS operations.)

\subsubsection{Support Concept}

(Preparer: This paragraph shall specify the support concept, including the following as appropriate:

a. Use of multipurpose test equipment.

b. Repair versus replacement criteria.

c. Levels of maintenance.

d. Maintenance and repair cycles.

e. Accessibility.

f. Other requirements not previously mentioned.)

\subsubsection{Impact on Existing Facilities}

(Preparer: This paragraph shall describe the impact of IMSS support requirements or other IMSS demands on the specific long-term plutonium metals and oxides storage facility to which this specification applies. For example, interfacing the IMSS with existing MC\&A databases or 
the influx of additional personnel associated with the IMSS might cause a problem. Note that interface requirements (e.g., power, space) are to be defined in Section 3.1.2).

\subsubsection{Impact on Existing Equipment}

(Preparer: This paragraph shall indicate what equipment, presently in use, might be withdrawn from service as a result of introduction of the IMSS at the specific long-term plutonium metals and oxides storage facility to which this specification applies. Or, if there is to be a sharing of resources, or some other effect caused by its introduction. Note that interface requirements( e.g., power, space) are to be defined in Section 3.1.2)

\subsection{Personnel}

(Preparer: This paragraph shall specify personnel requirements which must be integrated into the IMSS design for the specific long-term plutonium metals and oxides storage facility to which this specification applies. These requirements shall be stated in terms of numbers plus tolerance, and shall be the basis for contractor design and development decisions. Requirements stated in this paragraph shall also be the basis for determining system personnel training, training equipment, and training facility requirements. Personnel requirements shall include numbers and skills of support personnel for each operational mode (e.g. ,operation, maintenance) and the intended duty cycle, both normal and emergency.) 


\section{QUALIFICATION}

\subsection{General}

\subsubsection{Responsibility for Tests}

The contractor shall verify conformance with the requirements of Section 3 of this specification at appropriate locations and levels of assembly up to and including the total system. The contractor shall provide all personnel, facilities, test equipment, spares and expendables required for the qualification program.

\subsubsection{Special Tests and Examinations}

(Preparer: This paragraph shall specify any special tests and examinations which are required to develop an IMSS for the specific long-term plutonium metals and oxides storage facility to which this specification applies.)

\subsection{Qualification Methods}

To verify compliance with the requirements of Section 3, the IMSS shall be subjected to the qualification as defined in Section 4.3 (Table 4-1). The methods of qualification are defined as follows:

- Test. An action by which the operability, supportability, performance capability or other specified qualities of an item are verified when subjected to controlled conditions that are real or simulated. These verifications may require use of special test equipment and instrumentation to obtain quantitative data for analysis as well as qualitative data derived from displays and indicators inherent in the item(s) for monitor and control.

- Demonstration. An exhibition of the operability or supportability of an item under intended service-use conditions. These verifications are usually non-repetitive and are oriented almost exclusively toward acquiring qualitative data. Demonstrations may be accomplished by computer simulation.

- Analysis. A process used in lieu of or in addition to other qualification methods to verify compliance with requirements. The techniques typically include an interpretation or interpolation/extrapolation of analytical or empirical data under defined conditions or reasoning to show theoretical compliance with stated requirements. Analysis may include computer modeling or simulation.

- Inspection. An observation or examination of the product characteristics, or the review of applicable documentation to determine compliance with requirements. 
- Similarity. The process of comparing a current item with a previously qualified item, taking into consideration configuration, test data, application and/or environment. The evaluation must be documented and shall include: the test procedures/reports of the item to which similarity is claimed; a description of the difference(s) between the items; and the rationale for verification by similarity.

\subsection{Qualification Matrix}

Requirements of Section 3 shall be verified/qualified using the method specified for each requirement as shown below in Table 4-1. 
Table 4-1 Qualification Matrix

\begin{tabular}{|c|c|c|c|c|c|c|c|}
\hline & & 3ाएका & Ve & ificat & on $\mathrm{Me}$ & thod & the \\
\hline $\begin{array}{l}\text { Specification } \\
\text { Paragraph }\end{array}$ & Requirement Title & N/A & $\mathbf{T}$ & D & A & $\mathbf{I}$ & $\mathrm{s}$ \\
\hline 3.1 & System Definition & N/A & & & & & \\
\hline 3.1 .1 & System Diagram & & & & A & I & \\
\hline 3.1 .2 & Interface Definition & N/A & & & & & \\
\hline 3.1.2.1 & External Interfaces & & & & & & \\
\hline 3.1.2.2 & Internal Interfaces & & & & & & \\
\hline 3.1 .3 & Major Component List & & & & & I & \\
\hline 3.1 .4 & Government Furnished Property List & & & & & I & \\
\hline 3.1 .5 & Government Loaned Property List & & & & & $I$ & \\
\hline 3.2 .1 & Sensors & N/A & & & & & \\
\hline 3.2.1.1 & Storage Area Sensing & N/A & & & & & \\
\hline 3.2.1.1.1 & Radiological Conditions & & $\mathrm{T}$ & & & & \\
\hline 3.2.1.1.1.1 & Radiological Measurements & & & & & I & \\
\hline 3.2 .1 .2 & Package Sensing & N/A & & & & & \\
\hline 3.2.1.2.1 & Internal Container Pressure & & $\mathrm{T}$ & & & & \\
\hline 3.2.1.2.2 & Temperature Range & & $\mathrm{T}$ & & & & S \\
\hline 3.2.1.2.2.1 & Temperature Accuracy & & $\mathrm{T}$ & & & & $\mathrm{s}$ \\
\hline 3.2.1.2.3 & Package Weight Range & & $\mathrm{T}$ & & & & $S$ \\
\hline 3.2.1.2.3.1 & Package Weight Accuracy & & & D & & & \\
\hline 3.2.1.2.4 & Package Radiation Levels & & $\mathrm{T}$ & & & & $\mathrm{S}$ \\
\hline 3.2.1.2.5 & Package Condition & & & & A & I & \\
\hline 3.2 .1 .3 & Sensor Environmental Conditions & N/A & & & & & \\
\hline 3.2.1.3.1 & Sensor Operating Temperature & & $\mathrm{T}$ & & & & $\mathrm{s}$ \\
\hline 3.2.1.3.2 & Sensor Operating Humidity & & $\mathrm{T}$ & & & & $S$ \\
\hline 3.2.1.3.3 & $\begin{array}{l}\text { Sensor Operating Radiological } \\
\text { Environment }\end{array}$ & & $\mathrm{T}$ & & & & S \\
\hline 3.2.1.3.4 & Sensor Technology & & & D & & $I$ & \\
\hline 3.2 .2 & Data Acquisition & N/A & & & & & \\
\hline
\end{tabular}


Table 4-1 Qualification Matrix

\begin{tabular}{|c|c|c|c|c|c|c|c|}
\hline \multirow{2}{*}{$\begin{array}{l}\text { Specification } \\
\text { Paragraph }\end{array}$} & \multirow[b]{2}{*}{ Requirement Title } & \multicolumn{6}{|c|}{ Verification Method } \\
\hline & & NIA & $T$ & D & $\overline{\mathrm{A}}$ & $\mathrm{T}$ & s \\
\hline 3.2 .2 .1 & Data Categories & & & & & $\mathrm{I}$ & \\
\hline 3.2.3 & $\begin{array}{l}\text { Environmental Safety and Health } \\
\text { (ES\&H) }\end{array}$ & N/A & & & & & \\
\hline 3.2.3.1 & Alarm Parameters & & & D & & $\mathrm{I}$ & \\
\hline 3.2.3.2 & Radiological Instruments & & $\mathrm{T}$ & & & & $\mathrm{s}$ \\
\hline 3.2.3.3 & ANSI Compliance & & & & & $I$ & $s$ \\
\hline 3.2.3.4 & Gamma Radiation Monitoring & & $\mathrm{T}$ & & & & $\mathrm{s}$ \\
\hline 3.2.3.5 & Neutron Radiation Monitoring & & $\mathrm{T}$ & & & & $\mathrm{s}$ \\
\hline 3.2.3.6 & Monitoring and Test Interval & & & & & $I$ & \\
\hline 3.2.3.7 & Scheduling & & & & A & & \\
\hline 3.2.3.8 & Inspection Coordination & & & & A & & \\
\hline 3.2 .4 & $\begin{array}{l}\text { Materials Control and Accountability } \\
\text { (MC\&A) }\end{array}$ & N/A & & & & & \\
\hline 3.2.4.1 & Control & N/A & & & & & \\
\hline 3.2.4.1.1 & Alarm and Anti-tamper & N/A & & & & & \\
\hline 3.2.4.1.1.1 & Unauthorized/ Unaccompanied Entry & & $\mathrm{T}$ & $\mathrm{D}$ & & & $\mathbf{s}$ \\
\hline 3.2.4.1.1.2 & Auxiliary Power & & & $D$ & & & \\
\hline 3.2.4.1.1.3 & Intrusion Detection and Assessment & & $\mathrm{T}$ & & & $\mathrm{I}$ & $S$ \\
\hline 3.2.4.1.1.4 & Radio Frequency Device Compliance & & $\mathrm{T}$ & & & I & $\mathbf{s}$ \\
\hline 3.2.4.1.1.4.1 & Radio Frequency Device Limitations & & & & & I & \\
\hline 3.2.4.1.1.4.2 & $\begin{array}{l}\text { Radio Frequency Device Temporary } \\
\text { Usage }\end{array}$ & & & & & I & \\
\hline 3.2.4.2 & MC\&A Planning and Testing & N/A & & & & & \\
\hline 3.2.4.2.1 & Site MC\&A Plan & N/A & & & & & \\
\hline 3.2.4.2.1.1 & Graded Approach & & & & A & & \\
\hline 3.2.4.2.1.2 & Surveillance Interval & & & & & I & \\
\hline 3.2.4.2.1.3 & Surveillance Requirements & & & & & I & \\
\hline
\end{tabular}


Table 4-1 Qualification Matrix

\begin{tabular}{|c|c|c|c|c|c|c|c|}
\hline \multirow{2}{*}{$\begin{array}{l}\text { Specification } \\
\text { Paragraph }\end{array}$} & & \multicolumn{6}{|c|}{ Verification Method } \\
\hline & Requirement Title & N/A & $\mathbf{T}$ & D & A & I & S \\
\hline 3.2 .4 .2 .1 .4 & Threat Considerations & & & & & $I$ & \\
\hline 3.2.4.2.1.5 & Accounting System & & & & & I & \\
\hline 3.2.4.2.1.6 & Physical Inventories & & & & & I & \\
\hline 3.2.4.2.1.7 & Measurement Control & & & & & I & \\
\hline 3.2.4.2.1.8 & Control Limits & & & & & I & \\
\hline 3.2.4.2.1.9 & Loss Detection Elements & & & & & $\mathrm{I}$ & \\
\hline 3.2.4.2.1.10 & Response to Nuclear Material Alarms & & & & & I & \\
\hline 3.2.4.2.1.11 & Anomaly Resolution & & & & & I & \\
\hline 3.2.4.2.1.12 & Program Planning And Management & & & & & I & \\
\hline 3.2.4.2.1.13 & Performance Criteria & & & & & I & \\
\hline 3.2.4.2.1.14 & Administrative Control & & & & & I & \\
\hline 3.2.4.2.1.14.1 & Procedure Review and Approval & & & & & I & \\
\hline 3.2.4.2.1.14.2 & Formal Documentation & & & & & I & \\
\hline 3.2.4.2.2 & MC\&A Testing & N/A & & & & & \\
\hline 3.2 .4 .2 .2 .1 & IAEA and NRC Standards & & & & A & & \\
\hline 3.2.4.2.2.2 & ASTM and ANSI Standards & & & & A & & \\
\hline 3.2.4.2.2.2.1 & Working Standards & & & & A & & \\
\hline 3.2.4.2.2.3 & Test Conduct & & & & & I & $\mathbf{S}$ \\
\hline 3.2.4.2.2.4 & Functionality & & $\mathrm{T}$ & D & & & $\mathrm{S}$ \\
\hline 3.2 .4 .2 .2 .5 & Performance & & $\mathrm{T}$ & D & & & $\mathbf{S}$ \\
\hline 3.2.4.2.2.6 & Detection of Unauthorized Actions & & $\mathrm{T}$ & D & & & \\
\hline 3.2.4.2.2.7 & Surveillance Effectiveness & & $T$ & $\mathrm{D}$ & & & \\
\hline 3.2.4.2.2.8 & Documented Testing Program & & & $D$ & & I & \\
\hline 3.2.4.2.2.9 & Facility Specific Scope & & & & & I & \\
\hline 3.2.4.3 & Accountability & N/A & & & & & \\
\hline 3.2.4.3.1 & Package Identification & N/A & & & & & \\
\hline
\end{tabular}


Table 4-1 Qualification Matrix

\begin{tabular}{|c|c|c|c|c|c|c|c|}
\hline & & & $\mathrm{Ve}$ & ificat: & $\overline{\mathrm{nMe}}$ & thod & \\
\hline $\begin{array}{l}\text { Specification } \\
\text { Paragraph }\end{array}$ & Requirement Title & NA & $T$ & D & $\bar{A}$ & I & s \\
\hline 3.2.4.3.1.1 & Labels & & & D & & & \\
\hline 3.2.4.3.2 & Verification Measurement & N/A & & & & & \\
\hline 3.2.4.3.2.1 & Attribute Confirmation & & $\mathrm{T}$ & & & & \\
\hline 3.2.4.3.2.1.1 & $\begin{array}{l}\text { Confirmation Acceptance/ Rejection } \\
\text { Criteria }\end{array}$ & & $\mathrm{T}$ & & & & \\
\hline 3.2.4.3.2.2 & Control Limits & & & & A & & \\
\hline 3.2.4.3.2.3 & $\begin{array}{l}\text { Measurement Method Standard } \\
\text { Deviation }\end{array}$ & & & & A & & \\
\hline 3.2.4.3.2.4 & Statistical Sampling & & $\mathrm{T}$ & & A & & $S$ \\
\hline 3.2.4.3.3 & MC\&A Data Records & N/A & & & & & \\
\hline 3.2.4.3.3.1 & Package Identity and Location Accuracy & & & D & A & & \\
\hline 3.2.4.3.3.2 & Confirmation Data & & & & & $\mathrm{I}$ & \\
\hline 3.2.4.3.3.3 & Material Transfer Data & & & & & $\mathrm{I}$ & \\
\hline 3.2.4.3.3.4 & Gamma Data & & & & & I & \\
\hline 3.2.4.3.3.5 & Neutron Data & & & & & I & \\
\hline 3.2.4.3.3.6 & Weight Data & & & & & I & \\
\hline 3.2.4.3.3.7 & NDA Data & & & & & I & \\
\hline 3.2.4.3.3.8 & Chemistry Data & & & & & I & \\
\hline 3.2.4.3.3.9 & Analysis and Separation Data & & & & & I & \\
\hline 3.2.4.3.3.10 & Chemical Format Data & & & & & $\mathrm{I}$ & \\
\hline 3.2.4.3.3.11 & Tamper Indication Data & & & & A & $\mathrm{I}$ & \\
\hline 3.2.4.3.4 & Physical Inventory & N/A & & & & & \\
\hline 3.2.4.3.4.1 & Physical Inventory Program Compliance & & & & & $\mathrm{I}$ & \\
\hline 3.2 .4 .3 .4 .2 & Inventory Responsibilities & & & & & I & \\
\hline 3.2.4.3.4.3 & Inventory Frequency & & & & A & & \\
\hline 3.2.4.4 & Measurement Control & N/A & & & & & \\
\hline 3.2.4.4.1 & Weighing Systems Compliance & & & D & & & $\mathbf{s}$ \\
\hline
\end{tabular}


Table 4-1 Qualification Matrix

\begin{tabular}{|c|c|c|c|c|c|c|c|}
\hline & & & Ver & ificat & $\overline{\mathrm{nMe}}$ & thod & \\
\hline $\begin{array}{l}\text { Specification } \\
\text { Paragraph }\end{array}$ & Requirement Title & N/A & T & D & A & $T$ & S \\
\hline 3.2.4.4.2 & Weighing Systems Interface & & & $D$ & & & \\
\hline 3.2 .5 & Material Stability Monitoring & N/A & & & & & \\
\hline 3.2.5.1 & Material Physical Changes & & $\mathrm{T}$ & & & I & \\
\hline 3.2.5.2 & Container Distortion & & $\mathrm{T}$ & & & I & \\
\hline 3.2.5.2.1 & Pressurization & & $T$ & & & & \\
\hline 3.2.5.2.2 & Container Deformation & & & & A & & \\
\hline 3.2.5.3 & Plutonium Metal Temperature Limit & & $\mathrm{T}$ & & A & & \\
\hline 3.2.5.4 & Plutonium Oxide Temperature Limit & & $\mathrm{T}$ & & $A$ & & \\
\hline 3.2.5.5 & Temperature and Pressure Calculations & & & & A & & \\
\hline 3.2.5.6 & Baseline Package Inspections & & & & & I & \\
\hline 3.2.5.7 & Infant Mortality Monitoring Interval & & $T$ & & A & & \\
\hline 3.2.5.8 & Statistical Approach & & & & A & & \\
\hline 3.2 .6 & Container Integrity Monitoring & N/A & & & & & \\
\hline 3.2.6.1 & On-going Inspection Intervals & & & D & A & I & \\
\hline 3.2.6.2 & Statistical Approach & & & & A & $\mathrm{I}$ & \\
\hline 3.2 .7 & Data Transfer & N/A & & & & & \\
\hline 3.2.7.1 & Components & & & D & & & \\
\hline 3.2.7.2 & Software & & & D & & & \\
\hline 3.2 .8 & Data Storage, Analysis and Reporting & N/A & & & & & \\
\hline 3.2.8.1 & General & N/A & & & & & \\
\hline 3.2.8.1.1 & Database & & & D & & I & \\
\hline 3.2.8.1.2 & Compatibility & & & D & A & & \\
\hline 3.2.8.1.3 & Data Architecture & & & & A & I & \\
\hline 3.2.8.1.4 & Transferability & & & D & A & & \\
\hline 3.2.8.1.5 & Classified Data Separation & & & & & I & \\
\hline 3.2.8.1.5.1 & Classification Guide & & & & & I & \\
\hline
\end{tabular}




\section{Table 4-1 Qualification Matrix}

\begin{tabular}{|c|c|c|c|c|c|c|c|}
\hline \multirow{2}{*}{$\begin{array}{l}\text { Specification } \\
\text { Paragraph }\end{array}$} & & \multicolumn{6}{|c|}{ Verification Method } \\
\hline & Requirement Title & N/A & $\mathrm{T}$ & $\overline{\mathbf{D}}$ & A & $\bar{T}$ & $\sqrt{S}$ \\
\hline 3.2.8.1.6 & Data Access Control & & & D & & & \\
\hline 3.2 .8 .2 & Data Storage & N/A & & & & & \\
\hline 3.2.8.2.1 & Material Transfer Data & & & & & I & \\
\hline 3.2.8.2.2 & Material Location Data & & & & & I & \\
\hline 3.2.8.2.3 & Analysis and Separation Data & & & & & $I$ & \\
\hline 3.2.8.2.4 & Material Physical Description & & & & & I & \\
\hline 3.2.8.2.5 & LOI Test Data & & & & & $\mathrm{I}$ & \\
\hline 3.2.8.2.6 & Stabilization Test Data & & & & & I & \\
\hline 3.2.8.2.7 & Processing Conditions & & & & & $\mathrm{I}$ & \\
\hline 3.2.8.2.7.1 & Processing Data & & & & & I & \\
\hline 3.2.8.2.8 & Package Configuration Data & & & & & I & \\
\hline 3.2.8.2.9 & Packaging Date & & & & & I & \\
\hline 3.2.8.2.10 & Initial Radiation Field Data & & & & & $\mathrm{I}$ & \\
\hline 3.2.8.2.11 & Chemical Form Data & & & & & $\mathrm{I}$ & \\
\hline 3.2.8.2.12 & Material Source & & & & & I & \\
\hline 3.2.8.2.13 & Package Identification Number & & & & & $\mathrm{I}$ & \\
\hline 3.2.8.2.14 & Surveillance Results & & & & & I & \\
\hline 3.2.8.2.15 & Inspection Tests Performed & & & & & I & \\
\hline 3.2.8.2.16 & Individuals Performing Inspections & & & & & I & \\
\hline 3.2.8.2.17 & Inspection Dates & & & & & $\mathrm{I}$ & \\
\hline 3.2.8.2.18 & Fill Gas Data & & & & & I & \\
\hline 3.2.8.2.19 & Material Mass Data & & & & & 1 & \\
\hline 3.2.8.2.20 & Baseline Package Data & & & & & $\mathrm{I}$ & \\
\hline 3.2.8.2.21 & Container Lot Identification Number & & & & & I & \\
\hline 3.2.8.3 & Data Analysis & N/A & & & & & \\
\hline 3.2.8.3.1 & Weight Change Detection & & $\mathrm{T}$ & & & & \\
\hline
\end{tabular}


Table 4-1 Qualification Matrix

\begin{tabular}{|c|c|c|c|c|c|c|c|}
\hline & & & & iffeat & on Me & hod & 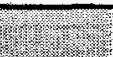 \\
\hline $\begin{array}{l}\text { Specification } \\
\text { Paragraph }\end{array}$ & Requirement Títle & N/A & $\mathrm{T}$ & $\mathbf{D}$ & A & I & $\mathbf{s}$ \\
\hline 3.2.8.3.2 & Temperature Change Detection & & $\mathrm{T}$ & & & & \\
\hline 3.2.8.3.3 & Errors/Discrepancies Detection & & $\mathrm{T}$ & D & A & & \\
\hline 3.2.8.3.4 & Data Omission Detection & & $\mathrm{T}$ & $\mathrm{D}$ & A & & \\
\hline 3.2.8.3.5 & Inventory Discrepancy Data & & $T$ & $D$ & A & & \\
\hline 3.2.8.4 & Data Reporting & N/A & & & & & \\
\hline 3.2.8.4.1 & Book Inventory Listings & & & D & & & \\
\hline 3.2.8.4.2 & Occurrence Reports & & & & A & I & \\
\hline 3.2 .9 & Site Specific Requirements & N/A & & & & & \\
\hline 3.2.9.1 & Package Transferability & & & & A & I & \\
\hline 3.3 & Quality Assurance & N/A & & & & & \\
\hline 3.3.1 & Quality Assurance Program & N/A & & & & & \\
\hline 3.3.1.1 & DOE Approval & & & & & I & \\
\hline 3.3.1.2 & Use of Standards & & & & & I & \\
\hline 3.3.1.3 & Change Review & & & & & I & \\
\hline 3.3.1.4 & CFR Compliance & & & & & I & \\
\hline 3.3.2 & Personnel Training and Qualification & N/A & & & & & \\
\hline 3.3.2.1 & Performance Training & & $\mathrm{T}$ & & & I & \\
\hline 3.3.2.2 & Continuing Training & & $\mathrm{T}$ & & & $I$ & \\
\hline 3.3.2.3 & $\begin{array}{l}\text { Documentation of Training } \\
\text { Requirements }\end{array}$ & & & & & I & \\
\hline 3.3.2.4 & Measurement Training Plan & & & & & I & \\
\hline 3.3.2.5 & Measurement Training & & & & & I & \\
\hline 3.3.2.6 & Proficiency Demonstration & & & & & $\mathrm{I}$ & \\
\hline 3.3.2.7 & Requalification & & & & & $\mathrm{I}$ & \\
\hline 3.3.2.8 & Certification & & $\mathrm{T}$ & & & I & \\
\hline 3.3.3 & Quality Improvement & N/A & & & & & \\
\hline 3.3.3.1 & Processes & & & & & I & \\
\hline
\end{tabular}


Table 4-1 Qualification Matrix

\begin{tabular}{|c|c|c|c|c|c|c|c|}
\hline & & & & ficatio & a Met & thod & (2) \\
\hline $\begin{array}{l}\text { Specification } \\
\text { Paragraph }\end{array}$ & Requirement Title & NTA & $\mathbf{T}$ & D & $\bar{A}$ & I & S \\
\hline 3.3.3.2 & Process Deficiency Identification & & & & & I & \\
\hline 3.3.4 & Documentation & N/A & & & & & \\
\hline 3.3.4.1 & Document Review and Approval & & & & & $\mathrm{I}$ & \\
\hline 3.3.4.2 & Container Fabrication Records & & & & & I & \\
\hline 3.3.4.2.1 & Outer Top Weld Data & & & & & I & \\
\hline 3.3.4.2.2 & Outer Bottom Weld Data & & & & & I & \\
\hline 3.3.4.2.3 & Inner Top Weld Data & & & & & I & \\
\hline 3.3.4.2.4 & Inner Bottom Weld Data & & & & & I & \\
\hline 3.3.4.2.5 & Inner Can Helium Leak Test Data & & & & & I & \\
\hline 3.3.4.2.6 & Outer Can Helium Leak Test Data & & & & & I & \\
\hline 3.3.4.3 & Weighing Instrument Data & & & & & I & \\
\hline 3.3.4.3.1 & Weight Data & & & & & I & \\
\hline 3.3 .5 & Process Requirements & N/A & & & & & \\
\hline 3.3.5.1 & Work Standards & & & & & I & \\
\hline 3.3.5.2 & Equipment Calibration & & & & & $\mathrm{I}$ & \\
\hline 3.3.5.3 & Leak Testing & & & & & I & \\
\hline 3.3.5.4 & Database Recording & & & & & I & \\
\hline 3.3.5.5 & Rejected Items & & & & & I & \\
\hline 3.3.5.6 & Acceptance Criteria & & & & & I & \\
\hline 3.3.5.7 & Inspection and Surveillance Prerequisites & & & & & $\mathrm{I}$ & \\
\hline 3.3.5.8 & Inspection and Surveillance Frequency & & & & & I & \\
\hline 3.3.5.9 & Safety Inspection Documentation & & & & & $\mathrm{I}$ & \\
\hline 3.3.5.10 & Surveillance Procedures & & & & & I & \\
\hline 3.3 .6 & Procurement & N/A & & & & & \\
\hline 3.3.6.1 & Performance & & & & & $I$ & \\
\hline 3.3.7 & Inspection and Acceptance Testing & N/A & & & & & \\
\hline
\end{tabular}


Table 4-1 Qualification Matrix

\begin{tabular}{|c|c|c|c|c|c|c|c|}
\hline & & $\sqrt{5}$ & Ve & fifica & $\operatorname{nn}$ & hod & \\
\hline $\begin{array}{l}\text { Specification } \\
\text { Paragraph }\end{array}$ & Requirement Title & N/A & $\mathbf{T}$ & $\overline{\mathbf{D}}$ & $\bar{A}$ & I & 5 \\
\hline 3.3.7.1 & Equipment Calibration & & & & & $\mathrm{I}$ & \\
\hline 3.3.7.2 & Measurement Methods & & & D & & & \\
\hline 3.4 & Reliability and Maintainability & N/A & & & & & \\
\hline 3.4.1 & Downtime Compliance & & $\mathrm{T}$ & $D$ & A & & $S$ \\
\hline 3.4 .2 & Downtime & & & & & I & \\
\hline 3.4.3 & Performance/Reliability Feedback & & & & & I & \\
\hline 3.4.4 & Problem Identification & & & & & I & \\
\hline 3.4.5 & Organizational Interfaces & & & & & II & \\
\hline 3.4 .6 & Operating Life & & & & A & & \\
\hline 3.5 & Logistics & N/A & & & & & \\
\hline 3.5 .1 & Support Concept & & & & & & \\
\hline 3.5 .2 & Impact on Existing Facilities & & & & & & \\
\hline 3.5.3 & Impact on Existing Equipment & & & & & & \\
\hline 3.6 & Personnel & & & & & & \\
\hline
\end{tabular}




\section{NOTES}

\subsection{Acronyms and Abbreviations}

Acronyms and abbreviations used in this specification shall be interpreted as follows:

$\begin{array}{ll}\text { Am } & \text { americium } \\ \text { ANSI } & \text { American National Standards Institute } \\ \text { ASTM } & \text { American Society of Testing and Materials } \\ \text { Cat I } & \text { Category I } \\ \text { CFR } & \text { Code of Federal Regulations } \\ \text { cm } & \text { centimeter } \\ \text { deg C } & \text { degrees Celsius } \\ \text { deg F } & \text { degrees Fahrenheit } \\ \text { DOE } & \text { Department of Energy } \\ \text { ES\&H } & \text { Environmental Safety and Health } \\ \text { GFE } & \text { Government Furnished Equipment } \\ \text { GFI } & \text { Government Furnished Information } \\ \text { GFS } & \text { Government Furnished Software } \\ \text { IAEA } & \text { International Atomic Energy Agency } \\ \text { IMSS } & \text { Integrated Monitoring and Surveillance System } \\ \text { kg } & \text { kilogram } \\ \text { LOI } & \text { Loss on Ignition } \\ \text { MC\&A } & \text { Materials Control and Accountability } \\ \text { NCC } & \text { neutron coincidence counter } \\ \text { NRC } & \text { Nuclear Regulatory Commission } \\ \text { psig } & \text { pounds per square inch gauge } \\ \text { Pu } & \text { plutonium } \\ \text { QA } & \text { Quality Assurance } \\ \text { QAP } & \text { Quality Assurance Program } \\ \text { QC } & \text { Quality Control } \\ \text { RADCON } & \text { Radiation Control } \\ \text { RF } & \text { Radio Frequency } \\ \text { SAR } & \text { Safety and Analysis Report } \\ \text { SNM } & \text { Special Nuclear Materials } \\ & \\ & \end{array}$




\subsection{Definitions}

Terms used in this specification shall be interpreted as follows:

Facility DOE facility for storing stabilized packages of plutonium metals and/or oxides.

Inspection Nondestructive examination of the condition of a container or package.

Monitoring Examination and/or testing of a sample of stored packages at specified intervals for a specific attribute or condition (e.g., temperature, pressure buildup, weight) and comparison of the data against previously obtained baseline data.

Nonintrusive Without penetrating the storage container(s).

Package A complete set of inner and outer 3013 storage containers, additional barriers (e.g., convenience can) plus the plutonium bearing material contents.

Qualification Process of verifying conformance of the IMSS with requirements by test, demonstration, analysis, inspection or similarity.

Site A geographic entity comprising land, buildings, and other facilities required to perform program objectives.

Surveillance

Action of monitoring nuclear materials and detecting unauthorized activities or anomalous conditions and for reporting material and facility status. The objective is the detection and assessment of conditions that may adversely affect safeguards and security (e.g., to detect anomalies and to report alarm conditions). 


\section{APPENDIX A REFERENCE DOCUMENT LIST}

\begin{tabular}{|l|l|l|}
\hline $\begin{array}{c}\text { DOCUMENT } \\
\text { NUMBER }\end{array}$ & \multicolumn{1}{|c|}{ DOCUMENT IITLE } & $\begin{array}{c}\text { DOCUMENT } \\
\text { DATE }\end{array}$ \\
\hline ANSI N 3171980 & $\begin{array}{l}\text { Performance Criteria for Instrumentation used for In-plant Plutonium } \\
\text { Monitoring }\end{array}$ & $11 / 8 / 78$ \\
\hline ANSI N323-1993 & Radiation Protection Instrumentation Test and Calibration & $9 / 13 / 77$ \\
\hline 10CFR 830.120 & Quality Assurance Requirements & $1 / 1 / 96$ \\
\hline DOE O 232.1-1 & Occurrence Reporting and Processing of Operations Information & $8 / 12 / 96$ \\
\hline DOE M 232.1-1 & Occurrence Reporting and Processing of Operations Information & $9 / 25 / 95$ \\
\hline DOE N 251.4 & Cancellation of Directives & $9 / 29 / 95$ \\
\hline DOE 420.1 & Facility Safety & $11 / 16 / 95$ \\
\hline DOE-470.1 & Safeguards and Security Program & $9 / 28 / 95$ \\
\hline DOE O 471.2 & Information Security Program & $9 / 28 / 95$ \\
\hline DOE M 471.2-1 & Manual for Classified Matter Protection and Control & $9 / 26 / 95$ \\
\hline DOE-471.2-2 & Manual for Classified Matter Protection & $9 / 26 / 95$ \\
\hline DOE-4330.4b & Maintenance Management Program & $2 / 10 / 94$ \\
\hline DOE-5000.3b & Occurrence Reporting and Processing of Operations Information & REPLACED \\
& & BY DOE \\
& & $232.1-1$ \\
\hline DOE-5480.20A & Personnel Selection, Qualification, and Training Requirements for & $11 / 15 / 94$ \\
\hline$\cdot$ & DOE Nuclear Facilities & \\
\hline DOE-5480.23 & Nuclear Safety Analysis Reports & $4 / 30 / 92$ \\
\hline DOE-5480.24 & Nuclear Criticality Safety & REPLACED \\
\hline & & BY DOE \\
& & 420.1 \\
\hline DOE-5630.11b & Safeguards and Security Program & $8 / 2 / 94$ \\
\hline DOE-5630.16A & Safeguards and Security Acceptance and Validation Testing Program & $6 / 3 / 93$ \\
\hline DOE-5632.1c & Protection and Control of Safeguards and Security Interests & $7 / 15 / 94$ \\
\hline DOE-M & $\begin{array}{l}\text { Manual for Protection and Control of Safeguards and Security } \\
\text { Interests }\end{array}$ & $7 / 15 / 94$ \\
\hline DOE2.1c-1 $5633.3 b$ & Control and Accountability of Nuclear Materials & $9 / 7 / 94$ \\
\hline DOE-5660.1b & Management of Nuclear Materials & $5 / 26 / 94$ \\
\hline DOE-5700.6c & Quality Assurance & $8 / 21 / 91$ \\
\hline $\begin{array}{l}\text { DOE-STD-3013- } \\
94\end{array}$ & $\begin{array}{l}\text { Criteria for Preparing and Packaging Plutonium Metals and Oxides } \\
\text { for Long-Term Storage }\end{array}$ & $\begin{array}{l}\text { REPLACED } \\
\text { BY DOE- } \\
\text { STD-3013-96 }\end{array}$ \\
\hline & & \\
\hline
\end{tabular}




\begin{tabular}{|c|c|c|}
\hline $\begin{array}{l}\text { DOCUMENT } \\
\text { NUMBER }\end{array}$ & DOCUMENT TITLE & $\begin{array}{l}\text { DOCUMENT } \\
\text { DATE }\end{array}$ \\
\hline $\begin{array}{l}\text { DOE-STD-3013- } \\
96\end{array}$ & $\begin{array}{l}\text { Criteria for Preparing and Packaging Plutonium Metals and Oxides } \\
\text { for Long-Term Storage }\end{array}$ & 9/96 \\
\hline DOE/EH-0526T & DOE Radiological Controls Manual & NOT DATED \\
\hline DOE/DP-0123T & $\begin{array}{l}\text { Assessment of Plutonium Storage Safety Issues at Department of } \\
\text { Energy Facilities }\end{array}$ & $1 / 94$ \\
\hline DNFSB 94-1 & Recommendation 94-1 Implementation Plan & $2 / 28 / 95$ \\
\hline PFA-TM-121A & Research and Development Plan & $11 / 95$ \\
\hline PFA-TM-144A & $\begin{array}{l}\text { 94-1 PFA Baseline Research \& Development Technical } \\
\text { Requirements Document, Final Draft }\end{array}$ & $3 / 25 / 96$ \\
\hline PFA-TM-346 & Criteria for Interim Storage of Plutonium Bearing Solid Materials & $11 / 95$ \\
\hline PNL-6534 & Health Physics Manual of Good Practices for Plutonium Facilities & $5 / 88$ \\
\hline $\begin{array}{l}\text { DE-AC03- } \\
\text { 96SF20948, } \\
\text { Attachment II }\end{array}$ & $\begin{array}{l}\text { Performance Specification, Stabilization and Packaging System } \\
\text { (SPS) of Plutonium Metals and Oxides }>50 \% \text { at Rocky Flats } \\
\text { Environmental Technology Site (RFETS) Building } 707\end{array}$ & $6 / 24 / 96$ \\
\hline PFA-TM-510 & $\begin{array}{l}\text { Excerpts from Pu SPS Container Specifications, Preliminary Draft } \\
\text { (Performance Specification - Stabilization and Packaging System } \\
\text { (SPS) of Plutonium Metals and Oxides }>50 \% \text { at Rocky Flats } \\
\text { Environmental Technology Site (RFETS) Building } 707\end{array}$ & $\begin{array}{l}\text { REPLACED } \\
\text { BY DE- } \\
\text { AC03-96SF } \\
\text { 20948,Atch } 2\end{array}$ \\
\hline LA-12999-MS & Plutonium Dioxide Storage: Conditions for preparation and handling & NOT DATED \\
\hline CG-SS-3 & Classification Guide for Safeguards and Security Information & $8 / 1 / 94$ \\
\hline $\begin{array}{l}\text { NOT } \\
\text { NUMBERED }\end{array}$ & $\begin{array}{l}\text { Radio Frequency Alarm Communications Guidelines for the } \\
\text { Protection of Category I Special Nuclear Materials, Memorandum } \\
\text { from Edward J. McCallum, Director, Office of Safeguards and } \\
\text { Security }\end{array}$ & $1 / 2 / 97$ \\
\hline $\begin{array}{l}\text { NOT } \\
\text { NUMBERED }\end{array}$ & $\begin{array}{l}\text { Guide for Implementation of DOE 5633.3b "Control and } \\
\text { Accountability of Nuclear Materials" }\end{array}$ & $4 / 7 / 95$ \\
\hline $\begin{array}{l}\text { NOT } \\
\text { NUMBERED }\end{array}$ & $\begin{array}{l}\text { Minimal Safeguards Practices for Plutonium Materials for Long-term } \\
\text { Storage per DOE-STD-3013 }\end{array}$ & NOT DATED \\
\hline
\end{tabular}




\section{APPENDIX B \\ REQUIREMENTS TRACEABILITY MATRIX}

\begin{tabular}{|c|c|c|c|}
\hline $\begin{array}{l}\text { Specification } \\
\text { Paragraph }\end{array}$ & $\begin{array}{c}\text { Requirement } \\
\text { Title } \\
\end{array}$ & Requirement Source & $\begin{array}{l}\text { Source } \\
\text { Paragraph }\end{array}$ \\
\hline 3.1 & $\begin{array}{l}\text { System } \\
\text { Definition }\end{array}$ & N/A & \\
\hline 3.1 .1 & $\begin{array}{l}\text { System } \\
\text { Diagram }\end{array}$ & Derived & \\
\hline 3.1 .2 & $\begin{array}{l}\text { Interface } \\
\text { Definition }\end{array}$ & N/A & \\
\hline 3.1 .2 .1 & $\begin{array}{l}\text { External } \\
\text { Interfaces }\end{array}$ & Derived & \\
\hline 3.1 .2 .2 & $\begin{array}{l}\text { Internal } \\
\text { Interfaces }\end{array}$ & Derived & \\
\hline 3.1.3 & $\begin{array}{l}\text { Major } \\
\text { Component List } \\
\end{array}$ & Derived & \\
\hline 3.1 .4 & $\begin{array}{l}\text { Government } \\
\text { Furnished } \\
\text { Property List }\end{array}$ & Derived & \\
\hline 3.1 .5 & $\begin{array}{l}\text { Government } \\
\text { Loaned } \\
\text { Property List }\end{array}$ & Derived & \\
\hline 3.2 .1 & Sensors & N/A & \\
\hline 3.2 .1 .1 & $\begin{array}{l}\text { Storage Area } \\
\text { Sensing }\end{array}$ & N/A & \\
\hline 3.2.1.1.1 & $\begin{array}{l}\text { Radiological } \\
\text { Conditions }\end{array}$ & Derived & \\
\hline 3.2 .1 .1 .1 .1 & \begin{tabular}{|l} 
Radiological \\
Measurements
\end{tabular} & Derived & \\
\hline 3.2 .1 .2 & $\begin{array}{l}\text { Package } \\
\text { Sensing }\end{array}$ & N/A & \\
\hline 3.2.1.2.1 & $\begin{array}{l}\text { Internal } \\
\text { Container } \\
\text { Pressure }\end{array}$ & $\begin{array}{l}\text { Derived from Criteria for Preparing and } \\
\text { Packaging Plutonium Metals and Oxides for } \\
\text { Long-Term Storage, DOE-STD-3013-96 }\end{array}$ & 4.2.2.b \\
\hline
\end{tabular}




\begin{tabular}{|c|c|c|c|}
\hline $\begin{array}{l}\text { Specification } \\
\text { Parragraph }\end{array}$ & $\begin{array}{l}\text { Requirement } \\
\text { Title }\end{array}$ & Requirement Source & $\begin{array}{l}\text { Source } \\
\text { Paragraph }\end{array}$ \\
\hline 3.2.1.2.2 & $\begin{array}{l}\text { Temperature } \\
\text { Range }\end{array}$ & Derived & \\
\hline 3.2.1.2.2.1 & $\begin{array}{l}\text { Temperature } \\
\text { Accuracy }\end{array}$ & Derived & \\
\hline 3.2.1.2.3 & $\begin{array}{l}\text { Package Weight } \\
\text { Range }\end{array}$ & $\begin{array}{l}\text { Derived from Criteria for Preparing and } \\
\text { Packaging Plutonium Metals and Oxides for } \\
\text { Long-Term Storage, DOE-STD-3013-96 }\end{array}$ & \\
\hline 3.2.1.2.3.1 & $\begin{array}{l}\text { Package Weight } \\
\text { Accuracy }\end{array}$ & $\begin{array}{l}\text { Control and Accountability of Nuclear } \\
\text { Materials, DOE 5633.3B }\end{array}$ & Chap II 4.e \\
\hline 3.2.1.2.4 & $\begin{array}{l}\text { Package } \\
\text { Radiation } \\
\text { Levels }\end{array}$ & Derived & \\
\hline 3.2.1.2.5 & $\begin{array}{l}\text { Package } \\
\text { Condition }\end{array}$ & Derived & \\
\hline 3.2.1.3 & $\begin{array}{l}\text { Sensor } \\
\text { Environmental } \\
\text { Conditions }\end{array}$ & N/A & \\
\hline 3.2.1.3.1 & \begin{tabular}{|l} 
Sensor \\
Operating \\
Temperature
\end{tabular} & Derived & \\
\hline 3.2.1.3.2 & $\begin{array}{l}\text { Sensor } \\
\text { Operating } \\
\text { Humidity }\end{array}$ & Derived & \\
\hline 3.2.1.3.3 & $\begin{array}{l}\text { Sensor } \\
\text { Operating } \\
\text { Radiological } \\
\text { Environment }\end{array}$ & Derived & \\
\hline 3.2.1.3.4 & $\begin{array}{l}\text { Sensor } \\
\text { Technology }\end{array}$ & $\begin{array}{l}\text { Criteria for Preparing and Packaging } \\
\text { Plutonium Metals and Oxides for Long- } \\
\text { Term Storage, DOE-STD-3013-96 }\end{array}$ & 4.2.1.c \\
\hline 3.2.2 & $\begin{array}{l}\text { Data } \\
\text { Acquisition }\end{array}$ & N/A & \\
\hline 3.2.2.1 & Data Categories & Derived & \\
\hline
\end{tabular}




\begin{tabular}{|c|c|c|c|}
\hline $\begin{array}{l}\text { Specification } \\
\text { Paragraph }\end{array}$ & $\begin{array}{l}\text { Requirement } \\
\text { Title }\end{array}$ & Requirement Source & $\begin{array}{l}\text { Source } \\
\text { Paragraph }\end{array}$ \\
\hline 3.2 .3 & $\begin{array}{l}\text { Environmental } \\
\text { Safety and } \\
\text { Health (ES\&H) }\end{array}$ & N/A & \\
\hline 3.2.3.1 & $\begin{array}{l}\text { Alarm } \\
\text { Parameters }\end{array}$ & $\begin{array}{l}\text { Derived from Health Physics Manual of } \\
\text { Good Practices for Plutonium Facilities, } \\
\text { PNL-6534 }\end{array}$ & 3.6 .6 \\
\hline 3.2.3.2 & $\begin{array}{l}\text { Radiological } \\
\text { Instruments }\end{array}$ & $\begin{array}{l}\text { Health Physics Manual of Good Practices for } \\
\text { Plutonium Facilities, PNL-6534 }\end{array}$ & 4.2 \\
\hline 3.2.3.3 & $\begin{array}{l}\text { ANSI } \\
\text { Compliance }\end{array}$ & $\begin{array}{l}\text { Radiation Protection Instrumentation Test } \\
\text { and Calibration, ANSI N323-1993 }\end{array}$ & 4. \\
\hline 3.2.3.4 & $\begin{array}{l}\text { Gamma } \\
\text { Radiation } \\
\text { Monitoring }\end{array}$ & Derived & \\
\hline 3.2.3.5 & $\begin{array}{l}\text { Neutron } \\
\text { Radiation } \\
\text { Monitoring }\end{array}$ & Derived & \\
\hline 3.2.3.6 & $\begin{array}{l}\text { Monitoring and } \\
\text { Test Interval }\end{array}$ & Derived & \\
\hline 3.2.3.7 & Scheduling & $\begin{array}{l}\text { Derived from Criteria for Preparing and } \\
\text { Packaging Plutonium Metals and Oxides for } \\
\text { Long-Term Storage, DOE-STD-3013-96 }\end{array}$ & 4.3 .5 \\
\hline 3.2.3.8 & $\begin{array}{l}\text { Inspection } \\
\text { Coordination }\end{array}$ & $\begin{array}{l}\text { Criteria for Preparing and Packaging } \\
\text { Plutonium Metals and Oxides for Long- } \\
\text { Term Storage, DOE-STD-3013-96 }\end{array}$ & 4.3 .4 \\
\hline 3.2 .4 & $\begin{array}{l}\text { Materials } \\
\text { Control and } \\
\text { Accountability } \\
\text { (MC\&A) }\end{array}$ & N/A & \\
\hline 3.2.4.1 & Control & N/A & \\
\hline 3.2.4.1.1 & $\begin{array}{l}\text { Alarm and } \\
\text { Anti-tamper }\end{array}$ & N/A & \\
\hline 3.2.4.1.1.1 & $\begin{array}{l}\text { Unauthorized/ } \\
\text { Unaccompanied } \\
\text { Entry }\end{array}$ & $\begin{array}{l}\text { Control and Accountability of Nuclear } \\
\text { Materials, DOE 5633.3B }\end{array}$ & Chap. III 3.b.1.d \\
\hline
\end{tabular}




\begin{tabular}{|c|c|c|c|}
\hline $\begin{array}{l}\text { Specification } \\
\text { Paragraph }\end{array}$ & $\begin{array}{c}\text { Requirement } \\
\text { Title }\end{array}$ & Requirement Source & $\begin{array}{c}\text { Sowrice } \\
\text { Paragraph }\end{array}$ \\
\hline 3.2.4.1.1.2 & $\begin{array}{l}\text { Auxiliary } \\
\text { Power }\end{array}$ & $\begin{array}{l}\text { Manual for Protection and Control of } \\
\text { Safeguards and Security Interests, DOE M } \\
5632.1 \mathrm{C}-1\end{array}$ & $\begin{array}{l}\text { Chap. VI 7, VII } \\
\text { 2.B. }\end{array}$ \\
\hline 3.2.4.1.1.3 & $\begin{array}{l}\text { Intrusion } \\
\text { Detection and } \\
\text { Assessment }\end{array}$ & $\begin{array}{l}\text { Manual for Protection and Control of } \\
\text { Safeguards and Security Interests, DOE M } \\
5632.1 \mathrm{C}-1\end{array}$ & Chap. VI \\
\hline 3.2.4.1.1.4 & $\begin{array}{l}\text { Radio } \\
\text { Frequency } \\
\text { Device } \\
\text { Compliance }\end{array}$ & $\begin{array}{l}\text { Radio Frequency Alarm Communications } \\
\text { Guidelines for the Protection of Category I } \\
\text { Special Nuclear Material, Memorandum } \\
\text { from Edward J. McCallum, Director, Office } \\
\text { of Safeguards and Security }\end{array}$ & \\
\hline 3.2.4.1.1.4.1 & $\begin{array}{l}\text { Radio } \\
\text { Frequency } \\
\text { Device } \\
\text { Limitations }\end{array}$ & $\begin{array}{l}\text { Derived from Radio Frequency Alarm } \\
\text { Communications Guidelines for the } \\
\text { Protection of Category I Special Nuclear } \\
\text { Material, Memorandum from Edward J. } \\
\text { McCallum, Director, Office of Safeguards } \\
\text { and Security }\end{array}$ & \\
\hline 3.2.4.1.1.4.2 & $\begin{array}{l}\text { Radio } \\
\text { Frequency } \\
\text { Device } \\
\text { Temporary } \\
\text { Usage }\end{array}$ & $\begin{array}{l}\text { Radio Frequency Alarm Communications } \\
\text { Guidelines for the Protection of Category I } \\
\text { Special Nuclear Material, Memorandum } \\
\text { from Edward J. McCallum, Director, Office } \\
\text { of Safeguards and Security }\end{array}$ & \\
\hline 3.2.4.2 & $\begin{array}{l}\text { MC\&A } \\
\text { Planning and } \\
\text { Testing }\end{array}$ & N/A & \\
\hline 3.2.4.2.1 & $\begin{array}{l}\text { Site MC\&A } \\
\text { Plan }\end{array}$ & N/A & \\
\hline 3.2.4.2.1.1 & $\begin{array}{l}\text { Graded } \\
\text { Approach }\end{array}$ & $\begin{array}{l}\text { Control and Accountability of Nuclear } \\
\text { Materials, DOE 5633.3B }\end{array}$ & Chap. III 3. \\
\hline 3.2.4.2.1.2 & $\begin{array}{l}\text { Surveillance } \\
\text { Interval }\end{array}$ & Derived & \\
\hline 3.2.4.2.1.3 & $\begin{array}{l}\text { Surveillance } \\
\text { Requirements }\end{array}$ & $\begin{array}{l}\text { Control and Accountability of Nuclear } \\
\text { Materials, DOE 5633.3B }\end{array}$ & $\begin{array}{l}\text { Chap. I 1.e.(1); } \\
\text { II.3.a.(4) }\end{array}$ \\
\hline 3.2.4.2.1.4 & $\begin{array}{l}\text { Threat } \\
\text { Considerations }\end{array}$ & $\begin{array}{l}\text { Control and Accountability of Nuclear } \\
\text { Materials, DOE 5633.3B }\end{array}$ & Chap. I 1.e. (1) \\
\hline
\end{tabular}




\begin{tabular}{|c|c|c|c|}
\hline $\begin{array}{l}\text { Specification } \\
\text { Paragraph }\end{array}$ & $\begin{array}{l}\text { Requirement } \\
\text { Title }\end{array}$ & Requirement Source & $\begin{array}{l}\text { Source } \\
\text { Parngraph }\end{array}$ \\
\hline 3.2 .4 .2 .1 .5 & $\begin{array}{l}\text { Accounting } \\
\text { System }\end{array}$ & $\begin{array}{l}\text { Control and Accountability of Nuclear } \\
\text { Materials, DOE 5633.3B }\end{array}$ & Chap. I 1. e. (1) \\
\hline 3.2 .4 .2 .1 .6 & $\begin{array}{l}\text { Physical } \\
\text { Inventories }\end{array}$ & $\begin{array}{l}\text { Control and Accountability of Nuclear } \\
\text { Materials, DOE 5633.3B }\end{array}$ & $\begin{array}{l}\text { Chap. I 1. e. (1), } \\
\text { Chap. II 3.a (4), } \\
\text { Chap. II 3. d (1) }\end{array}$ \\
\hline 3.2.4.2.1.7 & $\begin{array}{l}\text { Measurement } \\
\text { Control }\end{array}$ & $\begin{array}{l}\text { Control and Accountability of Nuclear } \\
\text { Materials, DOE 5633.3B }\end{array}$ & Chap. I 1.e. (1) \\
\hline 3.2.4.2.1.8 & Control Limits & $\begin{array}{l}\text { Control and Accountability of Nuclear } \\
\text { Materials, DOE 5633.3B }\end{array}$ & Chap. I 1.e. (1) \\
\hline 3.2.4.2.1.9 & $\begin{array}{l}\text { Loss Detection } \\
\text { Elements }\end{array}$ & $\begin{array}{l}\text { Control and Accountability of Nuclear } \\
\text { Materials, DOE 5633.3B }\end{array}$ & Chap. I 1.e. (1) \\
\hline 3.2.4.2.1.10 & $\begin{array}{l}\text { Response to } \\
\text { Nuclear } \\
\text { Material } \\
\text { Alarms }\end{array}$ & $\begin{array}{l}\text { Control and Accountability of Nuclear } \\
\text { Materials, DOE 5633.3B }\end{array}$ & Chap. I 1. e. (1) \\
\hline 3.2.4.2.1.11 & $\begin{array}{l}\text { Anomaly } \\
\text { Resolution }\end{array}$ & $\begin{array}{l}\text { Control and Accountability of Nuclear } \\
\text { Materials, DOE 5633.3B }\end{array}$ & Chap. I 1. e. (1) \\
\hline 3.2.4.2.1.12 & $\begin{array}{l}\text { Program } \\
\text { Planning And } \\
\text { Management }\end{array}$ & $\begin{array}{l}\text { Control and Accountability of Nuclear } \\
\text { Materials, DOE 5633.3B }\end{array}$ & Chap. I 1. e. (1) \\
\hline 3.2 .4 .2 .1 .13 & $\begin{array}{l}\text { Performance } \\
\text { Criteria }\end{array}$ & $\begin{array}{l}\text { Control and Accountability of Nuclear } \\
\text { Materials, DOE 5633.3B }\end{array}$ & Chap. I. 4.C \\
\hline 3.2.4.2.1.14 & $\begin{array}{l}\text { Administrative } \\
\text { Control }\end{array}$ & $\begin{array}{l}\text { Control and Accountability of Nuclear } \\
\text { Materials, DOE 5633.3B }\end{array}$ & Chap. I. 6. \\
\hline 3.2.4.2.1.14.1 & $\begin{array}{l}\text { Procedure } \\
\text { Review and } \\
\text { Approval }\end{array}$ & $\begin{array}{l}\text { Control and Accountability of Nuclear } \\
\text { Materials, DOE 5633.3B }\end{array}$ & Chap. I. 6.a. \\
\hline 3.2.4.2.1.14.2 & $\begin{array}{l}\text { Formal } \\
\text { Documentation }\end{array}$ & $\begin{array}{l}\text { Criteria for Preparing and Packaging } \\
\text { Plutonium Metals and Oxides for Long- } \\
\text { Term Storage, DOE-STD-3013-96 }\end{array}$ & 4.3 .2 \\
\hline 3.2.4.2.2 & MC\&A Testing & N/A & \\
\hline 3.2.4.2.2.1 & $\begin{array}{l}\text { IAEA and NRC } \\
\text { Standards }\end{array}$ & $\begin{array}{l}\text { Control and Accountability of Nuclear } \\
\text { Materials, DOE 5633.3B }\end{array}$ & $\begin{array}{l}\text { Chap. I 1. 0.; } \\
\text { Chap. II 4.d, 4.e }\end{array}$ \\
\hline
\end{tabular}




\begin{tabular}{|c|c|c|c|}
\hline $\begin{array}{l}\text { Specification } \\
\text { Paragraph }\end{array}$ & $\begin{array}{l}\text { Requirement } \\
\text { Title }\end{array}$ & Requirement Source & $\begin{array}{l}\text { Source } \\
\text { Paragraph }\end{array}$ \\
\hline 3.2.4.2.2.2 & $\begin{array}{l}\text { ASTM and } \\
\text { ANSI Standards }\end{array}$ & $\begin{array}{l}\text { Control and Accountability of Nuclear } \\
\text { Materials, DOE 5633.3B }\end{array}$ & $\begin{array}{l}\text { Chap. I 1. o.; } \\
\text { Chap II 4.d, 4.e }\end{array}$ \\
\hline 3.2.4.2.2.2.1 & $\begin{array}{l}\text { Working } \\
\text { Standards }\end{array}$ & $\begin{array}{l}\text { Control and Accountability of Nuclear } \\
\text { Materials, DOE 5633.3B }\end{array}$ & Chap II.4.e(1)(f) \\
\hline 3.2.4.2.2.3 & Test Conduct & $\begin{array}{l}\text { Control and Accountability of Nuclear } \\
\text { Materials, DOE 5633.3B } \\
\text { Manual for Protection and Control of } \\
\text { Safeguards and Security Interests, DOE M } \\
\text { 5632.1C-1 }\end{array}$ & $\begin{array}{l}\text { Chap I 4.b, Chap } \\
\text { III 2.,3.,5.; Chap } \\
\text { VI 8. }\end{array}$ \\
\hline 3.2.4.2.2.4 & Functionality & $\begin{array}{l}\text { Control and Accountability of Nuclear } \\
\text { Materials, DOE 5633.3B }\end{array}$ & Chap. I 4. b. (1) \\
\hline 3.2.4.2.2.5 & Performance & $\begin{array}{l}\text { Control and Accountability of Nuclear } \\
\text { Materials, DOE 5633.3B }\end{array}$ & Chap. I 4. b. (1) \\
\hline 3.2.4.2.2.6 & $\begin{array}{l}\text { Detection of } \\
\text { Unauthorized } \\
\text { Actions }\end{array}$ & $\begin{array}{l}\text { Control and Accountability of Nuclear } \\
\text { Materials, DOE 5633.3B }\end{array}$ & Chap. I Fig. I-4 \\
\hline 3.2.4.2.2.7 & $\begin{array}{l}\text { Surveillance } \\
\text { Effectiveness }\end{array}$ & $\begin{array}{l}\text { Control and Accountability of Nuclear } \\
\text { Materials, DOE 5633.3B }\end{array}$ & Chap. I Fig. I-4 \\
\hline 3.2.4.2.2.8 & $\begin{array}{l}\text { Documented } \\
\text { Testing } \\
\text { Program }\end{array}$ & $\begin{array}{l}\text { Control and Accountability of Nuclear } \\
\text { Materials, DOE 5633.3B }\end{array}$ & Chap. I 4. b. \\
\hline 3.2.4.2.2.9 & $\begin{array}{l}\text { Facility } \\
\text { Specific Scope }\end{array}$ & $\begin{array}{l}\text { Control and Accountability of Nuclear } \\
\text { Materials, DOE 5633.3B }\end{array}$ & Chap. I 4. c. \\
\hline 3.2.4.3 & Accountability & N/A & \\
\hline 3.2.4.3.1 & $\begin{array}{l}\text { Package } \\
\text { Identification }\end{array}$ & N/A & \\
\hline 3.2.4.3.1.1 & Labels & Derived & \\
\hline 3.2.4.3.2 & $\begin{array}{l}\text { Verification } \\
\text { Measurement }\end{array}$ & N/A & \\
\hline 3.2.4.3.2.1 & $\begin{array}{l}\text { Attribute } \\
\text { Confirmation }\end{array}$ & $\begin{array}{l}\text { Control and Accountability of Nuclear } \\
\text { Materials, DOE 5633.3B }\end{array}$ & Chap II 3.d \\
\hline
\end{tabular}




\begin{tabular}{|c|c|c|c|}
\hline $\begin{array}{l}\text { Specification } \\
\text { Paragraph }\end{array}$ & $\begin{array}{l}\text { Requirement } \\
\text { Title }\end{array}$ & Requirement Source & $\begin{array}{l}\text { Source } \\
\text { Paragraph }\end{array}$ \\
\hline 3.2.4.3.2.1.1 & $\begin{array}{l}\text { Confirmation } \\
\text { Acceptance/ } \\
\text { Rejection } \\
\text { Criteria }\end{array}$ & $\begin{array}{l}\text { Control and Accountability of Nuclear } \\
\text { Materials, DOE 5633.3B }\end{array}$ & Chap II 4.d(2) \\
\hline 3.2.4.3.2.2 & Control Limits & $\begin{array}{l}\text { Control and Accountability of Nuclear } \\
\text { Materials, DOE 5633.3B }\end{array}$ & Chap. I Fig. I-4 \\
\hline 3.2.4.3.2.3 & $\begin{array}{l}\text { Measurement } \\
\text { Method } \\
\text { Standard } \\
\text { Deviation }\end{array}$ & $\begin{array}{l}\text { Control and Accountability of Nuclear } \\
\text { Materials, DOE 5633.3B }\end{array}$ & Chap. I Fig. I-4 \\
\hline 3.2.4.3.2.4 & $\begin{array}{l}\text { Statistical } \\
\text { Sampling }\end{array}$ & $\begin{array}{l}\text { Control and Accountability of Nuclear } \\
\text { Materials, DOE 5633.3B }\end{array}$ & Chap II 3.d(1) \\
\hline 3.2.4.3.3 & $\begin{array}{l}\text { MC\&A Data } \\
\text { Records }\end{array}$ & $\mathrm{N} / \mathrm{A}$ & \\
\hline 3.2.4.3.3.1 & $\begin{array}{l}\text { Package } \\
\text { Identity and } \\
\text { Location } \\
\text { Accuracy }\end{array}$ & $\begin{array}{l}\text { Control and Accountability of Nuclear } \\
\text { Materials, DOE 5633.3B }\end{array}$ & Figure I-4 \\
\hline 3.2.4.3.3.2 & $\begin{array}{l}\text { Confirmation } \\
\text { Data }\end{array}$ & Derived & \\
\hline 3.2.4.3.3.3 & $\begin{array}{l}\text { Material } \\
\text { Transfer Data }\end{array}$ & $\begin{array}{l}\text { Control and Accountability of Nuclear } \\
\text { Materials, DOE 5633.3B }\end{array}$ & Chap. II 5. \\
\hline 3.2.4.3.3.4 & Gamma Data & Derived & \\
\hline 3.2.4.3.3.5 & Neutron Data & Derived & \\
\hline 3.2.4.3.3.6 & Weight Data & Derived & \\
\hline 3.2.4.3.3.7 & NDA Data & Derived & \\
\hline 3.2 .4 .3 .3 .8 & Chemistry Data & Derived & \\
\hline 3.2.4.3.3.9 & $\begin{array}{l}\text { Analysis and } \\
\text { Separation Data }\end{array}$ & $\begin{array}{l}\text { Derived from Criteria for Preparing and } \\
\text { Packaging Plutonium Metals and Oxides for } \\
\text { Long-Term Storage, DOE-STD-3013-96 }\end{array}$ & \\
\hline 3.2.4.3.3.10 & $\begin{array}{l}\text { Chemical } \\
\text { Format Data }\end{array}$ & $\begin{array}{l}\text { Derived from Criteria for Preparing and } \\
\text { Packaging Plutonium Metals and Oxides for } \\
\text { Long-Term Storage, DOE-STD-3013-96 }\end{array}$ & $\begin{array}{l}\text { 4.4.2.a.1; } \\
\text { 4.4.2.a.2 }\end{array}$ \\
\hline
\end{tabular}




\begin{tabular}{|c|c|c|c|}
\hline $\begin{array}{l}\text { Specification } \\
\text { Paragraph }\end{array}$ & $\begin{array}{l}\text { Requirement } \\
\text { Title }\end{array}$ & Requirement Source & $\begin{array}{l}\text { Source } \\
\text { Paragraph }\end{array}$ \\
\hline 3.2.4.3.3.11 & $\begin{array}{l}\text { Tamper } \\
\text { Indication Data }\end{array}$ & $\begin{array}{l}\text { Derived from Control and Accountability of } \\
\text { Nuclear Materials, DOE 5633.3b }\end{array}$ & Chap. I Fig. I-4 \\
\hline 3.2.4.3.4 & $\begin{array}{l}\text { Physical } \\
\text { Inventory }\end{array}$ & N/A & \\
\hline 3.2.4.3.4.1 & $\begin{array}{l}\text { Physical } \\
\text { Inventory } \\
\text { Program } \\
\text { Compliance }\end{array}$ & $\begin{array}{l}\text { Control and Accountability of Nuclear } \\
\text { Materials, DOE 5633.3B }\end{array}$ & Chap II 3. \\
\hline 3.2.4.3.4.2 & $\begin{array}{l}\text { Inventory } \\
\text { Responsibilities }\end{array}$ & $\begin{array}{l}\text { Control and Accountability of Nuclear } \\
\text { Materials, DOE 5633.3B }\end{array}$ & Chap. II 3.a.(2) \\
\hline 3.2.4.3.4.3 & $\begin{array}{l}\text { Inventory } \\
\text { Frequency }\end{array}$ & $\begin{array}{l}\text { Control and Accountability of Nuclear } \\
\text { Materials, DOE 5633.3B }\end{array}$ & Chap. II 3. \\
\hline 3.2.4.4 & $\begin{array}{l}\text { Measurement } \\
\text { Control }\end{array}$ & N/A & \\
\hline 3.2.4.4.1 & $\begin{array}{l}\text { Weighing } \\
\text { Systems } \\
\text { Compliance }\end{array}$ & $\begin{array}{l}\text { Control and Accountability of Nuclear } \\
\text { Materials, DOE 5633.3B }\end{array}$ & Chap. II 4.e \\
\hline 3.2.4.4.2 & $\begin{array}{l}\text { Weighing } \\
\text { Systems } \\
\text { Interface }\end{array}$ & Derived & \\
\hline 3.2 .5 & $\begin{array}{l}\text { Material } \\
\text { Stability } \\
\text { Monitoring }\end{array}$ & N/A & \\
\hline 3.2.5.1 & $\begin{array}{l}\text { Material } \\
\text { Physical } \\
\text { Changes }\end{array}$ & Derived & \\
\hline 3.2.5.2 & $\begin{array}{l}\text { Container } \\
\text { Distortion }\end{array}$ & $\begin{array}{l}\text { Derived from Criteria for Preparing and } \\
\text { Packaging Plutonium Metals and Oxides for } \\
\text { Long-Term Storage, DOE-STD-3013-96 }\end{array}$ & 4.3.3.c \\
\hline 3.2.5.2.1 & Pressurization & $\begin{array}{l}\text { Derived from Criteria for Preparing and } \\
\text { Packaging Plutonium Metals and Oxides for } \\
\text { Long-Term Storage, DOE-STD-3013-96 }\end{array}$ & 4.2.2.b \\
\hline 3.2.5.2.2 & $\begin{array}{l}\text { Container } \\
\text { Deformation }\end{array}$ & $\begin{array}{l}\text { Criteria for Preparing and Packaging } \\
\text { Plutonium Metals and Oxides for Long- } \\
\text { Term Storage, DOE-STD-3013-96 }\end{array}$ & 4.3.3.c \\
\hline
\end{tabular}




\begin{tabular}{|c|c|c|c|}
\hline $\begin{array}{l}\text { Specification } \\
\text { Paragraph }\end{array}$ & $\begin{array}{l}\text { Requirement } \\
\text { Title }\end{array}$ & Requirement Source & $\begin{array}{l}\text { Soarce } \\
\text { Paragraph }\end{array}$ \\
\hline 3.2.5.3 & $\begin{array}{l}\text { Plutonium } \\
\text { Metal } \\
\text { Temperature } \\
\text { Limit }\end{array}$ & $\begin{array}{l}\text { Criteria for Preparing and Packaging } \\
\text { Plutonium Metals and Oxides for Long- } \\
\text { Term Storage, DOE-STD-3013-96 }\end{array}$ & 4.1.2.b \\
\hline 3.2.5.4 & $\begin{array}{l}\text { Plutonium } \\
\text { Oxide } \\
\text { Temperature } \\
\text { Limit }\end{array}$ & $\begin{array}{l}\text { Derived from Material Stabilization and } \\
\text { Surveillance Working Group Memorandum, } \\
\text { dated 1/6/97 }\end{array}$ & \\
\hline 3.2.5.5 & $\begin{array}{l}\text { Temperature } \\
\text { and Pressure } \\
\text { Calculations }\end{array}$ & $\begin{array}{l}\text { Criteria for Preparing and Packaging } \\
\text { Plutonium Metals and Oxides for Long- } \\
\text { Term Storage, DOE-STD-3013-96 }\end{array}$ & 4.2.1.f. \\
\hline 3.2.5.6 & $\begin{array}{l}\text { Baseline } \\
\text { Package } \\
\text { Inspections }\end{array}$ & $\begin{array}{l}\text { Criteria for Preparing and Packaging } \\
\text { Plutonium Metals and Oxides for Long- } \\
\text { Term Storage, DOE-STD-3013-96 }\end{array}$ & 4.3.3.a \\
\hline 3.2.5.7 & $\begin{array}{l}\text { Infant Mortality } \\
\text { Monitoring } \\
\text { Interval }\end{array}$ & $\begin{array}{l}\text { Derived from Criteria for Preparing and } \\
\text { Packaging Plutonium Metals and Oxides for } \\
\text { Long-Term Storage, DOE-STD-3013-96 }\end{array}$ & Appendix A, 4.3 \\
\hline 3.2.5.8 & $\begin{array}{l}\text { Statistical } \\
\text { Approach }\end{array}$ & $\begin{array}{l}\text { Criteria for Preparing and Packaging } \\
\text { Plutonium Metals and Oxides for Long- } \\
\text { Term Storage, DOE-STD-3013-96 }\end{array}$ & 4.3.3.b \\
\hline 3.2 .6 & $\begin{array}{l}\text { Container } \\
\text { Integrity } \\
\text { Monitoring }\end{array}$ & N/A & \\
\hline 3.2.6.1 & $\begin{array}{l}\text { On-going } \\
\text { Inspection } \\
\text { Intervals }\end{array}$ & $\begin{array}{l}\text { Criteria for Preparing and Packaging } \\
\text { Plutonium Metals and Oxides for Long- } \\
\text { Term Storage, DOE-STD-3013-96 }\end{array}$ & $\begin{array}{l}\text { 4.3.5, 4.3.3.b, } \\
\text { 4.2.1.a, 4.2.1.d, } \\
4.2 .2 . c, 4.2 .3 . \mathrm{b}\end{array}$ \\
\hline 3.2.6.2 & $\begin{array}{l}\text { Statistical } \\
\text { Approach }\end{array}$ & $\begin{array}{l}\text { Criteria for Preparing and Packaging } \\
\text { Plutonium Metals and Oxides for Long- } \\
\text { Term Storage, DOE-STD-3013-96 }\end{array}$ & 4.3.3.b \\
\hline 3.2 .7 & Data Transfer & N/A & \\
\hline 3.2.7.1 & Components & Derived & \\
\hline 3.2.7.2 & Software & Derived & \\
\hline 3.2.8 & $\begin{array}{l}\text { Data Storage, } \\
\text { Analysis and } \\
\text { Reporting }\end{array}$ & N/A & \\
\hline
\end{tabular}




\begin{tabular}{|c|c|c|c|}
\hline $\begin{array}{l}\text { Specification } \\
\text { Paragraph }\end{array}$ & $\begin{array}{c}\text { Requirement } \\
\text { Title }\end{array}$ & Requirement Source & $\begin{array}{l}\text { Source } \\
\text { Paragraph }\end{array}$ \\
\hline 3.2.8.1 & General & N/A & \\
\hline 3.2.8.1.1 & Database & $\begin{array}{l}\text { Criteria for Preparing and Packaging } \\
\text { Plutonium Metals and Oxides for Long- } \\
\text { Term Storage, DOE-STD-3013-96 }\end{array}$ & 4.4.1 \\
\hline 3.2.8.1.2 & Compatibility & Derived & \\
\hline 3.2.8.1.3 & $\begin{array}{l}\text { Data } \\
\text { Architecture }\end{array}$ & Derived & \\
\hline 3.2.8.1.4 & Transferability & Derived & \\
\hline 3.2.8.1.5 & $\begin{array}{l}\text { Classified Data } \\
\text { Separation }\end{array}$ & Derived & \\
\hline 3.2.8.1.5.1 & $\begin{array}{l}\text { Classification } \\
\text { Guide }\end{array}$ & $\begin{array}{l}\text { Derived from Classification Guide for } \\
\text { Safeguards and Security Information, CG- } \\
\text { SS-3, E.O. Update }\end{array}$ & \\
\hline 3.2.8.1.6 & $\begin{array}{l}\text { Data Access } \\
\text { Control }\end{array}$ & $\begin{array}{l}\text { Control and Accountability of Nuclear } \\
\text { Materials, DOE 5633.3B }\end{array}$ & Chap. I 6. c. \\
\hline 3.2.8.2 & Data Storage & N/A & \\
\hline 3.2.8.2.1 & $\begin{array}{l}\text { Material } \\
\text { Transfer Data }\end{array}$ & $\begin{array}{l}\text { Derived from Control and Accountability of } \\
\text { Nuclear Materials, DOE 5633.3b }\end{array}$ & Chap. II 5. \\
\hline 3.2.8.2.2 & $\begin{array}{l}\text { Material } \\
\text { Location Data }\end{array}$ & $\begin{array}{l}\text { Criteria for Preparing and Packaging } \\
\text { Plutonium Metals and Oxides for Long- } \\
\text { Term Storage, DOE-STD-3013-96 }\end{array}$ & 4.4.2.d \\
\hline 3.2.8.2.3 & $\begin{array}{l}\text { Analysis and } \\
\text { Separation Data }\end{array}$ & $\begin{array}{l}\text { Derived from Criteria for Preparing and } \\
\text { Packaging Plutonium Metals and Oxides for } \\
\text { Long-Term Storage, DOE-STD-3013-96 }\end{array}$ & 4.4.2.c \\
\hline 3.2.8.2.4 & $\begin{array}{l}\text { Material } \\
\text { Physical } \\
\text { Description }\end{array}$ & $\begin{array}{l}\text { Derived from Criteria for Preparing and } \\
\text { Packaging Plutonium Metals and Oxides for } \\
\text { Long-Term Storage, DOE-STD-3013-96 }\end{array}$ & 4.4.2.a.8 \\
\hline 3.2.8.2.5 & LOI Test Data & $\begin{array}{l}\text { Criteria for Preparing and Packaging } \\
\text { Plutonium Metals and Oxides for Long- } \\
\text { Term Storage, DOE-STD-3013-96 }\end{array}$ & 4.4.2.2.4 \\
\hline 3.2.8.2.6 & $\begin{array}{l}\text { Stabilization } \\
\text { Test Data }\end{array}$ & Derived & \\
\hline
\end{tabular}




\begin{tabular}{|c|c|c|c|}
\hline $\begin{array}{l}\text { Specification } \\
\text { Paragraph }\end{array}$ & $\begin{array}{l}\text { Requirement } \\
\text { Tille }\end{array}$ & Requirement Source & $\begin{array}{l}\text { Sowrice } \\
\text { Paragriph }\end{array}$ \\
\hline 3.2.8.2.7 & $\begin{array}{l}\text { Processing } \\
\text { Conditions }\end{array}$ & $\begin{array}{l}\text { Criteria for Preparing and Packaging } \\
\text { Plutonium Metals and Oxides for Long- } \\
\text { Term Storage, DOE-STD-3013-96 }\end{array}$ & 4.4.2.a.7 \\
\hline 3.2.8.2.7.1 & Processing Data & Derived & \\
\hline 3.2.8.2.8 & $\begin{array}{l}\text { Package } \\
\text { Configuration } \\
\text { Data }\end{array}$ & $\begin{array}{l}\text { Criteria for Preparing and Packaging } \\
\text { Plutonium Metals and Oxides for Long- } \\
\text { Term Storage, DOE-STD-3013-96 }\end{array}$ & 4.4.2.b. 2 \\
\hline 3.2.8.2.9 & Packaging Date & $\begin{array}{l}\text { Criteria for Preparing and Packaging } \\
\text { Plutonium Metals and Oxides for Long- } \\
\text { Term Storage, DOE-STD-3013-96 }\end{array}$ & 4.4.2.b.3 \\
\hline 3.2.8.2.10 & $\begin{array}{l}\text { Initial Radiation } \\
\text { Field Data }\end{array}$ & $\begin{array}{l}\text { Criteria for Preparing and Packaging } \\
\text { Plutonium Metals and Oxides for Long- } \\
\text { Term Storage, DOE-STD-3013-96 }\end{array}$ & 4.4.2.b.4 \\
\hline 3.2.8.2.11 & $\begin{array}{l}\text { Chemical Form } \\
\text { Data }\end{array}$ & $\begin{array}{l}\text { Criteria for Preparing and Packaging } \\
\text { Plutonium Metals and Oxides for Long- } \\
\text { Term Storage, DOE-STD-3013-96 }\end{array}$ & $\begin{array}{l}\text { 4.4.2.a.1; } \\
\text { 4.4.2.a.2 }\end{array}$ \\
\hline 3.2.8.2.12 & Material Source & $\begin{array}{l}\text { Criteria for Preparing and Packaging } \\
\text { Plutonium Metals and Oxides for Long- } \\
\text { Term Storage, DOE-STD-3013-96 }\end{array}$ & 4.4.2.a.5 \\
\hline 3.2.8.2.13 & $\begin{array}{l}\text { Package } \\
\text { Identification } \\
\text { Number }\end{array}$ & $\begin{array}{l}\text { Derived from Criteria for Preparing and } \\
\text { Packaging Plutonium Metals and Oxides for } \\
\text { Long-Term Storage, DOE-STD-3013-96 }\end{array}$ & 4.2.1.e, 4.4.2.a.8 \\
\hline 3.2.8.2.14 & $\begin{array}{l}\text { Surveillance } \\
\text { Results }\end{array}$ & $\begin{array}{l}\text { Criteria for Preparing and Packaging } \\
\text { Plutonium Metals and Oxides for Long- } \\
\text { Term Storage, DOE-STD-3013-96 }\end{array}$ & 4.4.2.b.5 \\
\hline 3.2.8.2.15 & $\begin{array}{l}\text { Inspection Tests } \\
\text { Performed }\end{array}$ & $\begin{array}{l}\text { Criteria for Preparing and Packaging } \\
\text { Plutonium Metals and Oxides for Long- } \\
\text { Term Storage, DOE-STD-3013-96 }\end{array}$ & 4.4.2.c \\
\hline 3.2.8.2.16 & $\begin{array}{l}\text { Individuals } \\
\text { Performing } \\
\text { Inspections }\end{array}$ & $\begin{array}{l}\text { Criteria for Preparing and Packaging } \\
\text { Plutonium Metals and Oxides for Long- } \\
\text { Term Storage, DOE-STD-3013-96 }\end{array}$ & 4.4.2.c \\
\hline 3.2.8.2.17 & $\begin{array}{l}\text { Inspection } \\
\text { Dates }\end{array}$ & $\begin{array}{l}\text { Criteria for Preparing and Packaging } \\
\text { Plutonium Metals and Oxides for Long- } \\
\text { Term Storage, DOE-STD-3013-96 }\end{array}$ & 4.4.2.c \\
\hline
\end{tabular}




\begin{tabular}{|c|c|c|c|}
\hline $\begin{array}{l}\text { Specification } \\
\text { Paragraph }\end{array}$ & $\begin{array}{c}\text { Requirement } \\
\text { Title }\end{array}$ & Requirement Source & $\begin{array}{c}\text { Source } \\
\text { Parngraph }\end{array}$ \\
\hline 3.2.8.2.18 & Fill Gas Data & $\begin{array}{l}\text { Criteria for Preparing and Packaging } \\
\text { Plutonium Metals and Oxides for Long- } \\
\text { Term Storage, DOE-STD-3013-96 }\end{array}$ & 4.4.2.b.1 \\
\hline 3.2.8.2.19 & $\begin{array}{l}\text { Material Mass } \\
\text { Data }\end{array}$ & $\begin{array}{l}\text { Derived from Criteria for Preparing and } \\
\text { Packaging Plutonium Metals and Oxides for } \\
\text { Long-Term Storage, DOE-STD-3013-96 }\end{array}$ & 4.4.2.a.3 \\
\hline 3.2.8.2.20 & $\begin{array}{l}\text { Baseline : } \\
\text { Package Data }\end{array}$ & $\begin{array}{l}\text { Criteria for Preparing and Packaging } \\
\text { Plutonium Metals and Oxides for Long- } \\
\text { Term Storage, DOE-STD-3013-96 }\end{array}$ & 4.4.2.b.6 \\
\hline 3.2.8.2.21 & $\begin{array}{l}\text { Container Lot } \\
\text { Identification } \\
\text { Number }\end{array}$ & Derived & \\
\hline 3.2 .8 .3 & Data Analysis & N/A & \\
\hline 3.2.8.3.1 & $\begin{array}{l}\text { Weight Change } \\
\text { Detection }\end{array}$ & Derived & \\
\hline 3.2.8.3.2 & $\begin{array}{l}\text { Temperature } \\
\text { Change } \\
\text { Detection }\end{array}$ & Derived & \\
\hline 3.2.8.3.3 & $\begin{array}{l}\text { Errors/Discrepa } \\
\text { ncies Detection }\end{array}$ & $\begin{array}{l}\text { Control and Accountability of Nuclear } \\
\text { Materials, DOE 5633.3B }\end{array}$ & Chap. I 6. d. (2) \\
\hline 3.2.8.3.4 & $\begin{array}{l}\text { Data Omission } \\
\text { Detection }\end{array}$ & $\begin{array}{l}\text { Control and Accountability of Nuclear } \\
\text { Materials, DOE 5633.3B }\end{array}$ & Chap. I 6. d. (1) \\
\hline 3.2.8.3.5 & $\begin{array}{l}\text { Inventory } \\
\text { Discrepancy } \\
\text { Data }\end{array}$ & $\begin{array}{l}\text { Control and Accountability of Nuclear } \\
\text { Materials, DOE 5633.3B }\end{array}$ & Chap. I 6. d. (3) \\
\hline 3.2.8.4 & Data Reporting & N/A & \\
\hline 3.2.8.4.1 & $\begin{array}{l}\text { Book Inventory } \\
\text { Listings }\end{array}$ & $\begin{array}{l}\text { Control and Accountability of Nuclear } \\
\text { Materials, DOE 5633.3B }\end{array}$ & Chap. II.2.C.(3) \\
\hline 3.2.8.4.2 & $\begin{array}{l}\text { Occurrence } \\
\text { Reports }\end{array}$ & $\begin{array}{l}\text { Control and Accountability of Nuclear } \\
\text { Materials, DOE 5633.3B }\end{array}$ & Chap I 5 \\
\hline 3.2 .9 & $\begin{array}{l}\text { Site Specific } \\
\text { Requirements }\end{array}$ & N/A & \\
\hline 3.2.9.1 & $\begin{array}{l}\text { Package } \\
\text { Transferability }\end{array}$ & Derived & \\
\hline
\end{tabular}




\begin{tabular}{|c|c|c|c|}
\hline $\begin{array}{l}\text { Specification } \\
\text { Paragraph }\end{array}$ & $\begin{array}{l}\text { Requirement } \\
\text { Tite }\end{array}$ & Requirement Source & $\begin{array}{l}\text { Source } \\
\text { Paragraph }\end{array}$ \\
\hline 3.3 & $\begin{array}{l}\text { Quality } \\
\text { Assurance }\end{array}$ & N/A & \\
\hline 3.3.1 & $\begin{array}{l}\text { Quality } \\
\text { Assurance } \\
\text { Program }\end{array}$ & N/A & \\
\hline 3.3.1.1 & DOE Approval & $\begin{array}{l}\text { Derived from Quality Assurance } \\
\text { Requirements, 10CFR } 830.120\end{array}$ & a (1) (ii) \\
\hline 3.3.1.2 & $\begin{array}{l}\text { Use of } \\
\text { Standards }\end{array}$ & $\begin{array}{l}\text { Derived from Quality Assurance } \\
\text { Requirements, 10CFR } 830.120\end{array}$ & $\mathrm{~b}(1)$ \\
\hline 3.3.1.3 & Change Review & $\begin{array}{l}\text { Derived from Quality Assurance } \\
\text { Requirements, 10CFR } 830.120\end{array}$ & $b(3)$ \\
\hline 3.3.1.4 & $\begin{array}{l}\text { CFR } \\
\text { Compliance }\end{array}$ & $\begin{array}{l}\text { Derived from Quality Assurance } \\
\text { Requirements, 10CFR } 830.120\end{array}$ & c (1) (i) \\
\hline 3.3.2 & $\begin{array}{l}\text { Personnel } \\
\text { Training and } \\
\text { Qualification }\end{array}$ & N/A & \\
\hline 3.3.2.1 & $\begin{array}{l}\text { Performance } \\
\text { Training }\end{array}$ & $\begin{array}{l}\text { Derived from Quality Assurance } \\
\text { Requirements, 10CFR } 830.120\end{array}$ & c (1) (ii) \\
\hline 3.3.2.2 & $\begin{array}{l}\text { Continuing } \\
\text { Training }\end{array}$ & $\begin{array}{l}\text { Derived from Quality Assurance } \\
\text { Requirements, 10CFR 830.120 }\end{array}$ & c (1) (ii) \\
\hline 3.3.2.3 & $\begin{array}{l}\text { Documentation } \\
\text { of Training } \\
\text { Requirements }\end{array}$ & $\begin{array}{l}\text { Control and Accountability of Nuclear } \\
\text { Materials, DOE 5633.3B }\end{array}$ & Chap. I 1 (e) (1) \\
\hline 3.3.2.4 & $\begin{array}{l}\text { Measurement } \\
\text { Training Plan }\end{array}$ & $\begin{array}{l}\text { Control and Accountability of Nuclear } \\
\text { Materials, DOE 5633.3B }\end{array}$ & Chap. II 4.c.(1) \\
\hline 3.3.2.5 & $\begin{array}{l}\text { Measurement } \\
\text { Training }\end{array}$ & $\begin{array}{l}\text { Control and Accountability of Nuclear } \\
\text { Materials, DOE 5633.3B }\end{array}$ & Chap. II 4.c.(1) \\
\hline 3.3.2.6 & $\begin{array}{l}\text { Proficiency } \\
\text { Demonstration }\end{array}$ & $\begin{array}{l}\text { Control and Accountability of Nuclear } \\
\text { Materials, DOE 5633.3B }\end{array}$ & Chap. II 4.c.(2) \\
\hline 3.3.2.7 & Requalification & $\begin{array}{l}\text { Control and Accountability of Nuclear } \\
\text { Materials, DOE 5633.3B }\end{array}$ & Chap. II 4.c.(2) \\
\hline
\end{tabular}




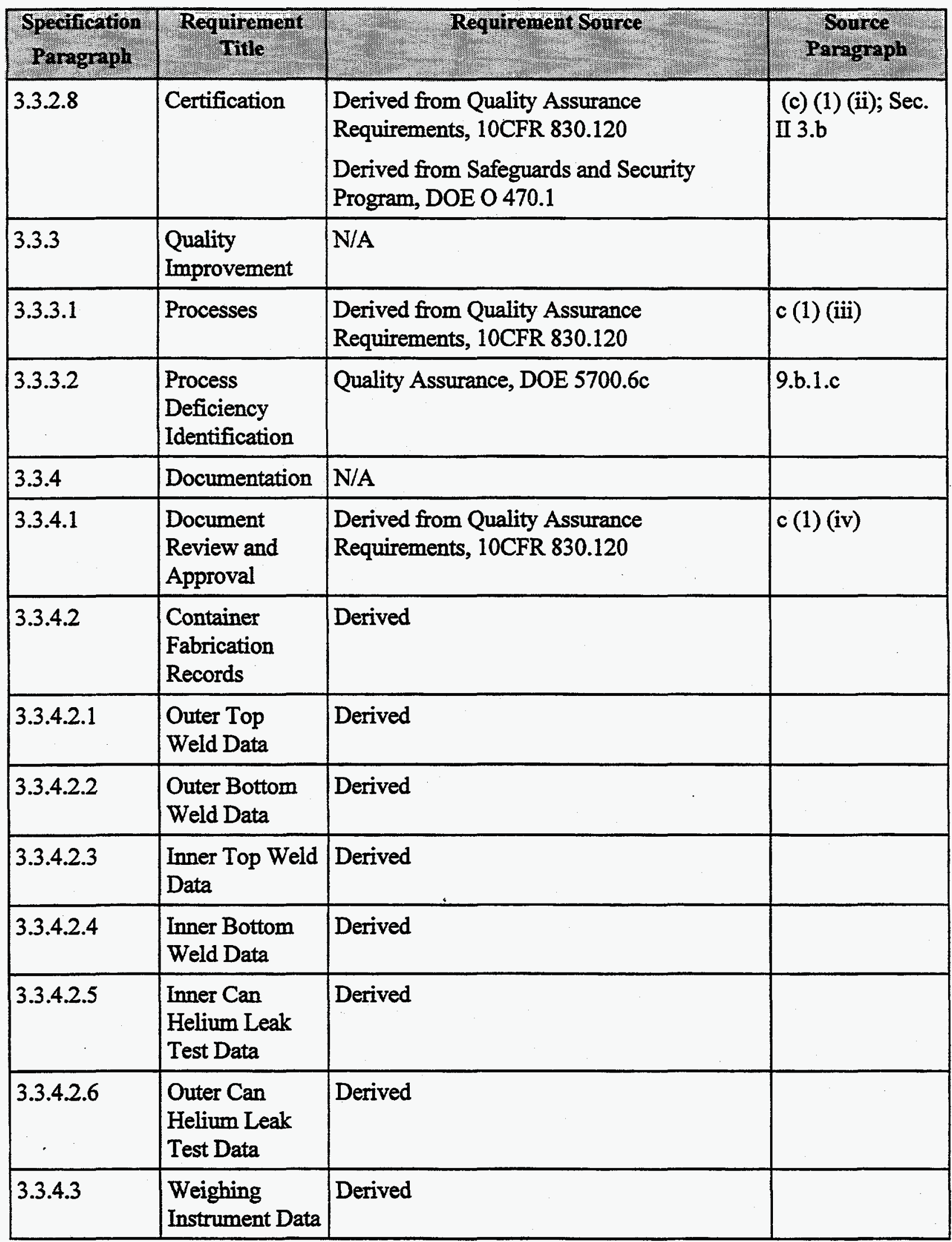




\begin{tabular}{|c|c|c|c|}
\hline $\begin{array}{l}\text { Specification } \\
\text { Paragraph }\end{array}$ & $\begin{array}{l}\text { Requirement } \\
\text { Title }\end{array}$ & Requirement Source & $\begin{array}{l}\text { Sowroce } \\
\text { Paragraph }\end{array}$ \\
\hline 3.3.4.3.1 & Weight Data & Derived & \\
\hline 3.3.5 & $\begin{array}{l}\text { Process } \\
\text { Requirements }\end{array}$ & N/A & \\
\hline 3.3.5.1 & Work Standards & $\begin{array}{l}\text { Derived from Quality Assurance } \\
\text { Requirements, 10CFR } 830.120\end{array}$ & $c(2)(i)$ \\
\hline 3.3.5.2 & $\begin{array}{l}\text { Equipment } \\
\text { Calibration }\end{array}$ & $\begin{array}{l}\text { Derived from Quality Assurance } \\
\text { Requirements, 10CFR } 830.120\end{array}$ & c (2) (i) \\
\hline 3.3.5.3 & Leak Testing & $\begin{array}{l}\text { Criteria for Preparing and Packaging } \\
\text { Plutonium Metals and Oxides for Long- } \\
\text { Term Storage, DOE-STD-3013-96 }\end{array}$ & 4.5.4.d \\
\hline 3.3.5.4 & $\begin{array}{l}\text { Database } \\
\text { Recording }\end{array}$ & $\begin{array}{l}\text { Criteria for Preparing and Packaging } \\
\text { Plutonium Metals and Oxides for Long- } \\
\text { Term Storage, DOE-STD-3013-96 }\end{array}$ & 4.5.4.f \\
\hline 3.3.5.5 & Rejected Items & $\begin{array}{l}\text { Criteria for Preparing and Packaging } \\
\text { Plutonium Metals and Oxides for Long- } \\
\text { Term Storage, DOE-STD-3013-96 }\end{array}$ & 4.3.a.3 \\
\hline 3.3.5.6 & $\begin{array}{l}\text { Acceptance } \\
\text { Criteria }\end{array}$ & $\begin{array}{l}\text { Criteria for Preparing and Packaging } \\
\text { Plutonium Metals and Oxides for Long- } \\
\text { Term Storage, DOE-STD-3013-96 }\end{array}$ & 4.3.a.2 \\
\hline 3.3.5.7 & $\begin{array}{l}\text { Inspection and } \\
\text { Surveillance } \\
\text { Prerequisites }\end{array}$ & $\begin{array}{l}\text { Criteria for Preparing and Packaging } \\
\text { Plutonium Metals and Oxides for Long- } \\
\text { Term Storage, DOE-STD-3013-96 }\end{array}$ & 4.3.a.1 \\
\hline 3.3.5.8 & $\begin{array}{l}\text { Inspection and } \\
\text { Surveillance } \\
\text { Frequency }\end{array}$ & $\begin{array}{l}\text { Criteria for Preparing and Packaging } \\
\text { Plutonium Metals and Oxides for Long- } \\
\text { Term Storage, DOE-STD-3013-96 }\end{array}$ & 4.3.a.4 \\
\hline 3.3.5.9 & $\begin{array}{l}\text { Safety } \\
\text { Inspection } \\
\text { Documentation }\end{array}$ & $\begin{array}{l}\text { Criteria for Preparing and Packaging } \\
\text { Plutonium Metals and Oxides for Long- } \\
\text { Term Storage, DOE-STD-3013-96 }\end{array}$ & 4.3 .2 \\
\hline 3.3.5.10 & $\begin{array}{l}\text { Surveillance } \\
\text { Procedures }\end{array}$ & Quality Assurance, DOE 5700.6c & Att. 1, A, 3, c \\
\hline 3.3 .6 & Procurement & N/A & \\
\hline 3.3.6.1 & Performance & $\begin{array}{l}\text { Derived from Quality Assurance } \\
\text { Requirements, 10CFR } 830.120\end{array}$ & c (2) (iii) \\
\hline
\end{tabular}




\begin{tabular}{|c|c|c|c|}
\hline $\begin{array}{l}\text { Specificafion } \\
\text { Paragraph } \\
\end{array}$ & $\begin{array}{c}\text { Requirement } \\
\text { Title }\end{array}$ & Requirement Source & $\begin{array}{c}\text { Source } \\
\text { Paragraph }\end{array}$ \\
\hline 3.3.7 & $\begin{array}{l}\text { Inspection and } \\
\text { Acceptance } \\
\text { Testing }\end{array}$ & N/A & \\
\hline 3.3.7.1 & $\begin{array}{l}\text { Equipment } \\
\text { Calibration }\end{array}$ & $\begin{array}{l}\text { Derived from Quality Assurance } \\
\text { Requirements, 10CFR } 830.120\end{array}$ & c (2) (iv) \\
\hline 3.3.7.2 & $\begin{array}{l}\text { Measurement } \\
\text { Methods }\end{array}$ & $\begin{array}{l}\text { Control and Accountability of Nuclear } \\
\text { Materials, DOE 5633.3B }\end{array}$ & Chap. II 4.b \\
\hline 3.4 & $\begin{array}{l}\text { Reliability and } \\
\text { Maintainability }\end{array}$ & N/A & \\
\hline 3.4.1 & $\begin{array}{l}\text { Downtime } \\
\text { Compliance }\end{array}$ & Derived & \\
\hline 3.4.2 & Downtime & Derived & \\
\hline 3.4 .3 & $\begin{array}{l}\text { Performance/ } \\
\text { Reliability } \\
\text { Feedback }\end{array}$ & $\begin{array}{l}\text { Maintenance Management Program, DOE- } \\
\text { 4330.4B }\end{array}$ & 10.a.4 \\
\hline 3.4 .4 & $\begin{array}{l}\text { Problem } \\
\text { Identification }\end{array}$ & $\begin{array}{l}\text { Maintenance Management Program, DOE- } \\
\text { 4330.4B }\end{array}$ & 10.a.5 \\
\hline 3.4 .5 & $\begin{array}{l}\text { Organizational } \\
\text { Interfaces }\end{array}$ & $\begin{array}{l}\text { Maintenance Management Program, DOE- } \\
\text { 4330.4B }\end{array}$ & 10.a.7 \\
\hline 3.4 .6 & Operating Life & Derived & \\
\hline 3.5 & Logistics & N/A & \\
\hline 3.5.1 & $\begin{array}{l}\text { Support } \\
\text { Concept }\end{array}$ & Derived & \\
\hline 3.5.2 & $\begin{array}{l}\text { Impact on } \\
\text { Existing } \\
\text { Facilities }\end{array}$ & Derived & \\
\hline 3.5 .3 & $\begin{array}{l}\text { Impact on } \\
\text { Existing } \\
\text { Equipment }\end{array}$ & Derived & \\
\hline 3.6 & Personnel & Derived & \\
\hline
\end{tabular}

